NBER WORKING PAPER SERIES

\author{
INTERNATIONAL RULES AND \\ INSTITUTIONS FOR TRADE POLICY
}

Robert W. Staiger

Working Paper No. 4962

\author{
NATIONAL BUREAU OF ECONOMIC RESEARCH \\ 1050 Massachusetts Avenue \\ Cambridge, MA 02138 \\ December 1994
}

I am grateful to Lael Brainard and Jim Brander who as my discussants at the Handbook Conference provided extremely detailed and helpful comments on an earlier draft, to Gene Grossman for providing an additional set of very helpful comments, and to Kyle Bagwell, Dale Henderson, Catherine Mann, participants in the Handbook Conference, and participants in the International Finance Workshop at the Federal Reserve Board and the NBER Conference on International Trade Rules and Institutions for helpful comments and discussion. I gratefully acknowledge financial support from the National Science Foundation. This paper is part of NBER's research program in International Trade and Investment. Any opinions expressed are those of the author and not those of the National Bureau of Economic Research.

(C) 1994 by Robert W. Staiger. All rights reserved. Short sections of text, not to exceed two paragraphs, may be quoted without explicit permission provided that full credit, including (C) notice, is given to the source. 


\title{
INTERNATIONAL RULES AND \\ INSTITUTIONS FOR TRADE POLICY
}

\begin{abstract}
What are the potential benefits from establishing international rules for the conduct of trade policy and how should these rules be designed? These questions are of central importance to the evolution of national trade policies in the post-war era, a period in which an elaborate system of international rules has evolved to facilitate the process of reciprocal trade liberalization. Yet the theory of trade policy has traditionally had little to say about these rules and the issues that underlie them. Below I review and synthesize several of the currents of a growing literature that is concerned with these questions. I attempt to accomplish three objectives: To describe the basic structure of international trade agreements as they exist in practice; to explore theoretically the normative consequences of actual and alternative trade agreements; and to offer some theoretically-based explanation for the structure of trade agreements that we observe. I attempt to achieve the first objective by describing the important features of the General Agreement on Tariffs and Trade. I attempt to achieve the latter two objectives by reviewing a body of literature and drawing out its implications as they relate to these issues.
\end{abstract}

Robert W. Staiger

Department of Economics

University of Wisconsin

1180 Observatory Drive

Madison, WI 53706

and NBER 


\section{Introduction}

What are the potential benefits from establishing international rules for the conduct of trade policy and how should these rules be designed? The answers to these questions are central to the evolution of national trade policies in the post-war era, a period characterized by sustained reciprocal trade liberalization. An elaborate system of international rules has evolved to facilitate this process, both at the multilateral level as embodied in the General Agreement on Tariffs and Trade (GATT), and at the regional and bilateral levels as well. These rules, which are as much about the way countries enforce their mutual commitments to reduce trade barriers and the permissible exceptions from these commitments as they are about the commitments themselves, reflect the relevant margins over which modern trade intervention is shaped.

Yet the theory of trade policy has traditionally had little to say about these rules and the issues that underlie them. Traditional economic analysis has focused primarily on the unilateral incentives that countries have to intervene in trade, and sometimes on the "retaliatory" outcomes that would emerge from the unfettered pursuit of such incentives across countries, without exploring the nature of the rules and institutions that countries might establish to mitigate these incentives. Recently, there has been increasing attention paid to formal economic analysis of these issues. This chapter will review and synthesize several of the currents of this growing literature.

My focus in reviewing the literature will be on its implications for the design of international institutions relating to reciprocal trade liberalization. ${ }^{1}$ North (1994, p. 360) defines institutions as "...the humanly devised constraints that structure human interaction. They are made up of formal constraints (e.g., rules, laws, constitutions), informal constraints (e.g., norms of behavior, conventions, self-imposed codes-of-conduct), and their enforcement characteristics. Together, they define the incentive structure of societies and specifically economies." I will restrict my attention to formal constraints and their enforcement characteristics, acknowledging that there may be important informal constraints that I am neglecting. Effectively, I am

\footnotetext{
${ }^{1}$ I am restricting my attention in this chapter to international institutions relating to reciprocal trade liberalization, and to a literature concerned with them, although in so doing I am ignoring the potential role played by national institutions, e.g, the U.S. Constitution (see Jackson, 1989, Ch. 3) or trade adjustment assistance programs (see Fung and Staiger, forthcoming), in this context.
} 
restricting my focus to international trade agreements, and will review a literature that relates to their design and operation. ${ }^{2}$

The specific objectives of this chapter are threefold: To describe the basic structure of international trade agreements as they exist in practice; to explore theoretically the normative consequences of actual and alternative trade agreements; and to offer some theoretically-based explanation for the structure of trade agreements that we observe. I will attempt to achieve the first objective by focusing on the important features of GATT. ${ }^{3}$ While GATT is far from the only explicit international trade agreement to which countries subject their trade policies, it represents the most important and well-developed set of multilateral trading rules, and has served as the standard over the post-war period by which multilateral trading practices are judged. ${ }^{4}$ Moreover, the broad features of GATT are, with some exceptions, common to many regional trade agreements. ${ }^{5}$ I will attempt to achieve the latter two objectives by reviewing a body of literature and drawing out its implications as they relate to these issues.

The remainder of this chapter is organized as follows. The next section describes the nature of international trade agreements as they exist in practice and some of the major themes that characterize the behavior of trade intervention in their presence. Section 3 then discusses why and in what circumstances countries might wish to enter into international trade agreements. The next four sections review a literature which is related to the collection of rules and institutions that define an international trade agreement: Section 4 is devoted to issues of enforcement,

\footnotetext{
2 My emphasis in this chapter is on understanding and evaluating the nature and operation of the rules that define an international trade agreement rather than the particular pattern of concessions that emerge from negotiation (on the latter, see for example Baldwin and Clarke, 1987).

${ }^{3}$ While the Uruguay Round of GATT negotiations has resulted in an agreement which calls for the creation of a World Trade Organization (WTO) to replace GATT, I will describe the features of GATT rather than the WTO both because GATT is familiar while the WTO has yet to be tested and because many of the broad features of GATT that I will emphasize will be shared by the WTO.

${ }^{4}$ It is not my purpose here to trace the history of international agreements in trade policy matters, though this history certainly precedes GATT (see, for example, Jackson, 1969, Chapter 2).

${ }^{5}$ The most-favored nation (MFN) rule of GATT is one attribute that is generally absent from regional trade agreements, although the United States included an MFN clause in each of the bilateral tariff-reduction agreements it negotiated between 1934 and 1939 under the Reciprocal Trade Agreements Act of 1930 (Winters, 1990).
} 
Section 5 to exploring the process of multilateral and bilateral liberalization, Section 6 to safeguard measures and managed trade, and Section 7 to countervailing duty and antidumping laws. The final section concludes by discussing some of the major gaps in this literature and possible directions for future research.

\section{The Structure of International Trade Agreements}

International trade agreements codify attempts by countries to mutually restrain the degree of trade intervention from what might otherwise obtain. Generally, they include three basic elements: Substantive obligations (e.g., elimination of quotas, tariff commitments); permissible exceptions to those obligations (e.g., general escape clauses, provisions for the imposition of antidumping duties); and enforcement mechanisms (e.g., dispute settlement procedures, provisions for retaliation). Through the provisions of a trade agreement countries therefore typically agree to mutually restrain both their "baseline" levels of trade intervention and their use of "special protection," with the effectiveness of these restraints determined ultimately by the strength of the enforcement mechanisms in place. As such, where international trade agreements operate, a country's trade intervention can be understood to reflect its baseline commitments, its current use of exceptions, and the operation and effectiveness of enforcement procedures.

In this section I will attempt to provide an overview of the important features of trade rules and institutions that typify international trade agreements. As mentioned above, I will do this by describing the key features of GATT. I will then sketch in broad terms the nature of trade liberalization among industrialized economies under the rules of GATT that have motivated the literature I am addressing. ${ }^{6}$ There is a great deal of complexity in the system of rules that has developed under GATT and I could not possibly address all the details here (authoritative references on GATT rules and procedures include Dam, 1970, Hudec, 1975, and Jackson, 1969, 1989). Instead, my purpose is first to sketch at the broadest level the basic elements of GATT, and then to distill a few broad themes in the ways that trade liberalization has occurred under GATT rules. My description of GATT follows Jackson $(1969,1989)$. Bhagwati $(1988,1991)$ provides a more detailed elaboration of the way in which trade liberalization has proceeded under

\footnotetext{
6 I confine my discussion here to the rules as applied to industrialized countries, since many of the rules which I discuss do not apply to developing economies as a result of GATT's Article XVIII.
} 


\section{GATT.}

\subsection{The Structure of GATT}

Broadly speaking, a description of GATT can be organized under three main headings: Organizational structure and procedural rules; substantive obligations; and exceptions to those obligations.

\subsubsection{Organizational Structure and Procedural Rules}

GATT's organizational structure and procedural rules themselves raise interesting and important institutional questions. They dictate such issues as how countries can amend the agreement, the rules of membership and voting, the role of the Secretariat and the structure and purpose of committees, and the provisions for dispute resolution and enforcement of GATT obligations. Many of these issues are especially interesting because GATT was never supposed to be an international organization, and so made no provisions for several of the institutional features that would be necessary to make the agreement operational. ${ }^{7}$ Nevertheless I will focus only on the last of these, that is, on the provisions for dispute resolution and enforcement of GATT obligations.

Ultimately, as with any international trade agreement, GATT obligations will only be honored if the incentives created by the agreement are compatible with the desired behavior. That is, since no external enforcement mechanism exists to punish GATT violations, meaningful GATT commitments must be self-enforcing, with violations deterred by the credible threat of subsequent retaliation. This points to provisions for dispute resolution and enforcement of GATT obligations as essential to the workings of GATT. Dam (1970) provides a concise statement of the need to view international trade agreements as necessarily self-enforcing:

The best guarantee that a commitment of any kind will be kept (particularly in an international setting where courts are of limited importance and, even more important, marshals and jails are nonexistent) is that the parties continue to view adherence to their agreement as in their mutual interest....

Thus, the GATT system, unlike most legal systems,..., is not designed to exclude self-help in the form of retaliation. Rather, retaliation, subjected to established procedures and kept within prescribed bounds, is made the heart of the GATT system. (Dam, 1970, pp.80-81)

\footnotetext{
${ }^{7}$ As originally conceived, GATT was drafted as a trade agreement and was designed to include only those clauses that were normally found in trade agreements and deemed to be essential to protect the value of tariff concessions. The proposed International Trade Organization (ITO) was supposed to have furnished the necessary organizational and secretariat support for GATT, but the ITO never came into being (see Jackson, 1969, pp. 4253).
} 
While dispute settlement procedures are spread throughout GATT, the key provisions are contained in Articles XXII and XXIII. These provisions typically are invoked on the grounds of "nullification or impairment" of benefits expected under the agreement and do not require a violation of the legal obligations under GATT. Nullification or impairment has been interpreted to include actions taken by one country "... which harmed the trade of another, and which 'could not reasonably have been anticipated' by the other at the time it negotiated for a concession" (Jackson, 1989, p. 95). ${ }^{8}$ The procedure for settling disputes proceeds through three stages: Consultation between or among the parties in the dispute; investigation, ruling and recommendation by a GATT panel; and as a last resort, authorization for one or more countries to suspend GATT obligations against another, i.e., retaliation. In practice, the greatest emphasis has been placed on consultation and negotiation rather than on retaliation, although a number of GATT disputes have resulted in unauthorized retaliation, and other disputes between GATT members have occurred outside GATT procedures entirely (see Kovenoch and Thursby, 1992). ${ }^{9}$

This observation points to a basic tension in the GATT dispute settlement procedures between what Jackson (1989, pp. 92-93) has called "rule integrity" and "negotiation/conciliation." That is, GATT dispute settlement procedures seem to acknowledge the essential role of retaliatory threats in preventing unilateral deviations from the agreement but at the same time display an aversion to actually allowing those threats to be carried out. This tension is reflected in the view of legal scholars as to the role and purpose of dispute settlement procedures in a well-functioning GATT system. Again I will quote from Dam (1970), although similar views can be found elsewhere, e.g., Jackson (1989):

...The principal tariff function of the GATT, beyond the sponsoring of rounds of tariff negotiations, are therefore (1) to prevent contracting parties from upsetting the balance of advantages by unilateral withdrawals of concessions, (2) to maintain the general level of liberalization already achieved by assuring that retaliatory action by other contractig parties is not greater than necessary to reestablish the balance of advantages and does not set off further rounds of

\footnotetext{
${ }^{8}$ The ambiguity of this phrase led to efforts to define three conditions for prima facie nullification or impairment: The breach of an obligation; the use of a domestic subsidy to inhibit imports in certain cases; and the use of quantitative restrictions. The burden of proof that no nullification or impairment occurred then falls on the country which breached or took such actions (see Jackson, 1989, p. 95).

${ }^{9}$ While a major accomplishment of the WTO as proposed under the Uruguay Round Agreement is to strengthen dispute settlement procedures by, for example, streamlining the process and preventing blockage and delay of panel reports, it is not clear that such changes will result in gréater reliance on actual retaliation (see, fo example, Jackson, 1989, p. 110).
} 
retaliatory actions, and (3) to establish procedures for original withdrawals of concessions and for subsequent retaliatory withdrawals so that disputes among contracting parties do not destroy confidence in the GATT system. (Dam, 1970, p. 80)

As enumerated by Dam, function (1) amounts to preventing violations of the agreement, function (2) amounts to containing the retaliation required to carry out function (1), and function (3) amounts to achieving functions (1) and (2) without losing credibility of the entire GATT system!

In part this tension may reflect several different and not necessarily consistent purposes that the dispute settlement procedures of GATT were designed to serve (Jackson, 1969, p. 169). These purposes included securing compliance with GATT obligations through the threat of punitive sanctions, but there was also a view that these procedures should be used primarily to maintain the balance between obligations and benefits in a changing environment. ${ }^{10}$ This suggests that several categories of disputes were envisioned, each requiring a different kind of response. Indeed, during the original drafting of GATT's dispute settlement procedures statements were made suggesting the need for "more rigorous retorsion" in circumstances where the offending action was "abusive" (Jackson, 1969, p.169). In any event, as I will discuss below, both sides of this tension have been picked up in the economics literature that has focused on the role of dispute settlement procedures in international trade agreements.

\subsection{Substantive Obligations}

Jackson (1969, p. 194) groups the substantive obligations contained in GATT into three categories: Tariff commitments (Articles II and XXVIII bis.); most-favored-nation (MFN) treatment (Article I); and a series of other commitments that together represent a "code of

\footnotetext{
${ }^{10}$ Jackson (1969, p. 170) quotes a statement made by a draftsmen of GATTs Article XXIII, which I reproduce here:
}

We shall achieve, under the Charter, if our negotiations are successful, a careful balance of the interests of the contracting States. This balance rests upon certain assumptions as to the character of the underlying situation in the years to come. And it involves a mutuality of obligations and benefits. If, with the passage of time, the underlying situation should change or the benefits accorded any member should be impaired, the balance would be destroyed. It is the purpose of Article 35 [comesponding to GATT Article XXIII] to restore this balance by providing for compensatory adjustment in the obligations which the Member has assumed. This adjustment will not be made unless the Member has asked that it be made. And it is then the function of the Organization to insure that compensatory action will not be carried out to such a level that the balance would be tipped the other way. What we have really provided, in the last analysis, is not that retaliation shall be invited or sanctions invoked, but that a balance of interests once established, shall be maintained. [U.N. Doc. EPCT/A/PV.6 at 5 (1947)] 
conduct" regarding non-tariff barriers (Articles III, VII through XI, and XV through XVII). At the broadest level these provisions amount to an obligation to concentrate national protective measures into the form of tariffs (and possibly subsidies), to apply them on an MFN basis, and to honor any tariff ceilings that are agreed to as "concessions" in a GATT negotiation.

With regard to tariff commitments and MFN treatment, several points should be noted. Tariff commitments made under GATT are in the form of "bindings," with the actual tariff not to exceed the bound duty rate. MFN treatment requires further that goods of any member country be given no less favorable treatment than goods of any other country, so that tariff concessions granted to one country must be extended to all member countries. There are also specific obligations that accompany a tariff binding that are meant to insure that the binding can not be undone by other governmental measures, such as non-tariff charges, new subsidies, or new methods of classifying or valuing goods. Tariff bindings can be altered through time, however, and indeed, GATT provides for its members to sponsor "rounds" of negotiations to lower the general level of tariff bindings "from time to time."11

The remaining substantive obligations of GATT, which amount to a "code of conduct" regarding non-tariff barriers, include provisions for national treatment of all goods once they have cleared customs, a basic prohibition against quotas, restrictions on the behavior of state trading and monopolies, limits on the use of certain subsidies, standards for customs administration, and limits on the use of exchange controls. These obligations apply generally, and are not limited to products that have been the subject of negotiated tariff agreements. As such, they differ from the specific obligations on non-tariff measures that accompany a tariff binding and which are meant merely to assure that the value of negotiated tariff concessions are not undone by nontariff measures. Instead, these obligations amount to a broad determination that protection afforded by MFN tariffs is preferable -- possibly in part because it is thought more amenable to

\footnotetext{
"Under Article XXVIII, GATT members can also renegotiate their tariff bindings every three years, but are obligated to keep the overall tariff levels from rising as a result of such renegotiations. Interestingly, Article XXVIII bis., which provides for the periodic rounds of trade-liberalizing negotiations that have become synonymous with GATT, was not included in the original GATT agreement, and was added only after it became clear that the proposed ITO, which was to have sponsored such negotiations, would never come into force (Jackson, 1969, pp. 220-221).
} 
negotiated liberalization -- to a system of non-tariff barriers. ${ }^{12}$ This is evident in the broader structure of GATT itself which, while requiring of its members a code of conduct with regard to the use of non-tariff barriers, does not place restrictions on the use of MFN tariffs except for those restrictions ("bindings") that members may voluntarily negotiate. ${ }^{13}$

\subsubsection{Exceptions}

While the substantive obligations of GATT represent an attempt at the international level to restrain the incentives for trade intervention that may exist at the national level, countries are not held rigidly to these obligations. Instead, GATT provides for various exceptions that can be invoked in certain circumstances. Jackson $(1969$, p. 536) describes three kinds of exceptions in GATT: "Universal" exceptions, that can apply to any GATT obligation; "particular" exceptions, that can only apply to certain GATT obligations; and "tacit" exceptions, which refer to GATT obligations that can be avoided without consequence.

Important universal exceptions include the following: General waivers (Article XXV), as well as departures from GATT obligations authorized under the dispute settlement procedures in cases of "nullification and impairment," each of which requires specific GATT approval; escape clause actions (Article XIX), which require notification to GATT; and exceptions for health, welfare, and national security reasons (Articles XX and XXI), which require no such notification. Important particular exceptions include exceptions from tariff bindings in the case of antidumping duties and countervailing duties (Article VI), opportunities for renegotiation and modification of tariff schedules (Article XXVIII), and exceptions from MFN treatment in the case of free trade

\footnotetext{
${ }^{12}$ The question of whether "tariffication" (or more generally limiting the choice of instruments) is enforceable, and if so whether it is desirable, is an interesting and important question, but not one which I will consider in this chapter. Copeland (1990) assumes that tariffication is not enforceable and that countries will set non-tariff barriers non-cooperatively, but shows that there are still gains from negotiating tariff agreements in this setting. Copeland (1989) shows that, if countries can limit themselves to two instruments (tariffs and quotas), then negotiations on either tariffs or quotas alone, leaving the other instrument to be set non-cooperatively, leads to essentially equivalent outcomes. Under the assumption that countries can limit themselves to the use of one (common) instrument, Webb (1984) and Bagwell and Staiger (1990) show that tariffication can facilitate trade liberalization.

${ }^{13}$ GATT's creation was accompanied by an initial round of tariff negotiations at Geneva in 1947, but these initial tariff reductions were not seen as a quid pro quo for membership. In fact, there is no legal obligation in GATT for members to enter into tariff negotiations.
} 
areas and customs unions (Article XXIV). ${ }^{14}$ Examples of tacit exceptions can be found with reference to tariff surcharges and "residual" quotas originally imposed in connection with balance-of-payments difficulties.

The large number and variety of permissible exceptions suggests that GATT "obligations" are not what they might appear, and indeed they are not. Dam (1970) observes:

The goal of achieving and maintaining a relatively low tariff level has resulted in a system that contrasts sharply with the international law of treaties and the domestic law of contracts in the world's major legal systems. Public international law and domestic contract law tend to view agreements as binding even when one of the parties no longer regards continued performance of the agreement to be in its interest (although the two bodies of law give some recognition to the principle of rebus sic stantibus, under which an agreement is not held binding if the circumstances have fundamentally changed in a way that was not anticipated by the parties at the time of the making of the agreement). This indicates that, with many obvious exceptions, domestic contract law and public international law are more concerned with assuring that commitments made are carried out than with promoting the making of agreements in the first place.

The GATT has a special interest in seeing that as many agreements for the reduction of tariffs as possible are made. Enforcement of bindings is important in the GATT insofar as such enforcement gives contracting parties the confidence necessary to rely upon tariff concessions offered by other contracting parties. But because of the economic nature of tariff concessions and the domestic political sensitivity inherently involved in trade issues, a system that made withdrawals of concessions impossible would tend to discourage the making of concessions in the first place. It is better, for example, that 100 commitments should be made and that 10 should be withdrawn than that only 50 commitments should be made and that all of them should be kept. (Dam, 1970, p. 80)

Still, while numerous, the exceptions provided for in GATT are not without some (at least potentially) disciplining structure. Particular exceptions, for example from tariff bindings in the case of antidumping duties and countervailing duties and from MFN treatment in the case of free trade areas and customs unions, are to be used only in relatively narrowly defined circumstances, or, as in the case of renegotiation of tariff schedules, are to be accomplished without increasing the overall level of protection. The universal exceptions embodied in GATT waivers and those authorized under dispute settlement procedures must receive GATT approval, and so must at some level be deemed in the general interest. ${ }^{15}$ In contrast, escape clause actions, which allow a temporary response to "changed circumstances," are less disciplined by GATT in that they do not require GATT approval but only notification. Finally, it is only over exceptions for noneconomic reasons (health, welfare, security) that countries are given relatively complete autonomy

14 GATT Articles XII, XIV, and XVIII also provide exceptions to the prohibitions on quantitative restrictions for balance-of-payments purposes.

${ }^{15}$ Although what is perceived to be in the "general interest" may correspond to that which does not thwart the national interests of a powerful member. For example, the agriculture waiver granted to the United States essentially "legitimized" prior actions otherwise in violation of GATT. 
(no notification is required). ${ }^{16}$ In a sense, the effectiveness of GATT as an institution hinges upon its ability to strike the appropriate balance between requiring adherence to a rigid set of rules and disciplines and at the same time providing for sufficient flexibility so that countries see it in their own interests to abide by these rules in a changing and uncertain environment.

\subsection{Trade Liberalization under GATT}

As noted above, the original focus of GATT was on the "tariffication" of existing nontariff trade barriers and on reducing tariff levels on a multilateral MFN basis. This focus was gradually overtaken by other issues which took on increasing importance as the process of multilateral liberalization matured over the eight Rounds of GATT negotiations that have occurred since 1947. But the first five Rounds, undertaken between 1947 and 1961, were devoted almost exclusively to reducing the level of tariffs, and tariff reduction has continued to be an important objective up through the most recently completed (Uruguay) Round. The success with which countries have been able to negotiate reciprocal tariff reductions under GATT has been remarkable, first for the depth of the tariff reductions achieved through this process (world tariffs have been reduced by 90 percent, from an average ad valorem rate of 40 percent in 1947 to 4 percent in 1994) but also for the extended period of time over which the process has occurred.

However, accompanying the success in reducing baseline tariff levels has been the rising importance of various kinds of exceptions and the increasing prominence of enforcement difficulties. Among the most important and potentially troublesome exceptions have been the following: Exceptions from MFN treatment associated with the formation of regional trading blocs; exceptions for "special protection" associated with safeguards actions; and exceptions for antidumping and countervailing duty actions. These exceptions have played an important role in shaping the pattern of protection under GATT. The increasing prominence of enforcement difficulties has been crystallized with the controversy surrounding the United States use of "section 301" procedures. Since these developments have served to motivate the literature I will survey below, I will elaborate briefly on each.

\footnotetext{
${ }^{16}$ In this case, the practical protection against abuse must rely on the claim of nullification and impairment in the context of dispute settlement procedures.
} 
Regionalism: Exceptions to the MFN principle afforded to pairs or groups of countries who wish to liberalize on a reciprocal basis more quickly than the pace set by multilateral negotiations, and who are willing to completely eliminate tariffs on "substantially all" of their trade, have allowed the formation of a number of free trade areas and customs unions. The most visible episodes of regional bloc formation falling within this exception include: (i) the formation of the original European Community with the Treaty of Rome in 1957; the subsequent enlargement to its present twelve-member size, and the further elimination of its remaining internal barriers to become the European Union of today; and (ii) the signing of the U.S.-Canada free trade agreement and its extension to include Mexico. These regional initiatives raise a number of important questions regarding their interpretation and role in the broader efforts to liberalize trade on a multilateral basis.

Managed Trade: The rise in special protection that has accompanied the gradual reduction in baseline tariffs has served to alter the rate of expansion of imports and exports from what might have occurred absent such intervention. ${ }^{17}$ This form of protection has been epitomized by the growing use of Voluntary Export Restraints (VERs), Voluntary Import Expansions (VIEs), Orderly Market Arrangements (OMAs), and tariffs that are designed to suit the needs of a particular sector, and has given rise to the term "managed trade" to describe an environment in which relatively low levels of baseline protection are combined with the use of special protection to dampen underlying changes in trade flows and trade balances. An important question is whether the use of special protection and the forms that it has taken can be understood within the context of the broader trade agreements within which it arose.

Unfair Trade Laws: Whereas safeguard actions carry with them no implication of wrongdoing, antidumping and countervailing duty procedures are intended to be used against "unfair" trading practices of foreign exporters and their governments, respectively. Antidumping duties can be imposed when foreign firms are found to be "dumping," that is, exporting at a price below either the home-market selling price or the cost of production. Countervailing duties can be imposed to offset foreign government subsidies. The increasing frequency with which these so-

\footnotetext{
${ }^{17}$ The increasing relative importance of special protection has been widely noted, and attempts to quantify this trend include Page (1979) and Bergsten and Cline (1983). Trefler (1993) estimates the effects of non-tariff barriers on U.S. imports in 1983 and concludes that these effects are very large.
} 
called "unfair trade" laws have been invoked, and the belief shared by many countries that the multilateral rules governing their use are ineffectual, brings into question the purpose to which these laws are being put and the effects that they have on trade.

Aggressive Unilateralism: Finally, a growing frustration on the part of the United States that the dispute settlement procedures of GATT were not sufficient to enforce its rights within the agreement, and that policies in important areas of trade and investment which fell outside any agreement were left completely undisciplined, led to the inclusion of section 301 in the 1974 Trade Act and to its subsequent amendments. Section 301 provides the authority and procedures for the President to enforce unilaterally the perceived U.S. rights under international trade agreements where such agreements exist, and to respond to certain "unfair" foreign practices where agreements do not exist. ${ }^{18}$ Associated with the rise of this so-called "aggressive unilateralism" are important questions relating to the role served by multilateral dispute settlement procedures and the consequences of adopting alternative enforcement methods.

\subsection{What is the role of GATT?}

It is one thing to describe the reciprocal liberalization that has occurred under GATT during the past 50 years, but there is still the question, what has been the role of GATT in promoting and maintaining this process? One possible answer is that GATT represents a codification of the post-war effort to achieve a liberal multilateral trading environment. Under this interpretation, GATT is simply an explicit record of how countries attempt to liberalize trade in a way that is self-enforcing, and GATT's existence plays no independent role in making this liberalization possible. But there are other possibilities.

At a minimum GATT probably serves a coordination function, providing countries with a forum for communication and a means for seeking out and implementing efficient equilibria. Beyond that, there is some evidence (see Jackson, 1989, pp.88-91) that GATT legal precedent often affects GATT deliberations and the outcomes of dispute settlement procedures. It is also possible that the existence of an explicit dispute settlement procedure in GATT instills in countries a sense of "international obligation" (Hudec, 1990, Jackson, 1989, Kovenoch and

\footnotetext{
${ }^{18}$ In 1984 the EC adopted a new commercial policy instrument that shares several common elements with section 301, although there are also significant differences (see Jackson, 1989, pp. 107-109).
} 
Thursby, 1992) to the agreement which makes the act of violating the agreement costly, independent of any future response from trading partners that a violation might trigger, and thereby strengthens enforcement capabilities associated with the agreement. Finally, GATT may serve a possible information-dissemination role, either in providing objective information to countries directly involved in a dispute (Hungerford, 1991) or in coordinating multilateral punishments (Maggi, 1994).

Which, if any, of these institutional roles GATT plays is an important issue that has only just begun to be explored. But even if it plays no such role, GATT is still worth studying as an explicit representation of the most detailed and well-developed effort to liberalize trade on a multilateral basis in the post-war world. In what follows, I will attempt to bring out those features of liberalization under GATT that the literature seems well-equipped to explain, and also highlight some features that are more difficult to interpret.

\section{Strategic Interaction and the Benefits from International Trade Agreements}

In this section I will postpone consideration of the design of international trade agreements, and instead ask under what conditions the benefits of entering into such agreements might exist. An answer to this question requires a definition of what is meant by an international trade agreement. For the purposes of this chapter I will define an international trade agreement as a collection of rules regarding the conduct of trade policy to which compliance requires some form of enforcement mechanism, that is, where unilateral incentives to violate the rules of the agreement are kept in check by the desire to avoid punishments that are themselves specified in the agreement. Whether these punishments rely on external enforcement mechanisms or are carried out by parties to the agreement and must themselves be incentive compatible is for the moment not important: Below I will discuss a number of papers focusing on the issue of enforcement that take the latter view, and other papers that assume instead the existence of an external enforcement mechanism in order to focus on different dimensions of trade agreements. What this definition does preclude is consideration of the gains that might come from simple (or "pure") coordination of trade policies across countries, as could arise for example in a one-shot tariff game when there are multiple Nash equilibria, since in such instances the coordinated 
outcome is free of incentive problems in the usual sense. ${ }^{19}$ However, the definition of international trade agreements that I adopt is consistent with the institutional structure I have outlined above and does represent a view which permeates the literature that I discuss below. ${ }^{20}$

There are two environments within which the effects of adhering to international trade agreements of the sort I have just defined have been explored in the economics literature. ${ }^{21}$ One environment is characterized by the presence of governments (i) whose private agents make decisions which, at least collectively at the national level, have a perceptible impact on trading partners, (ii) who have the capability and unilateral incentive to manipulate these private sector decisions through trade policy intervention for their international "beggar-thy-neighbor" effects, and (iii) who look mutually to international trade agreements as a way to mitigate these unilateral incentives. The other is characterized by the presence of governments that are limited in their ability to use trade policy instruments as effective tools for achieving domestic policy goals, and who look to international trade agreements as a way to enhance the effectiveness of trade policy tools for this purpose. In the former case, it is the strategic interaction across governments in their trade policy choices that gives rise to the possibility of beneficial international agreements. In the latter case, it is the strategic interaction between a government and its domestic private agents that makes international agreements look potentially attractive. Common to both environments is the notion that an international trade agreement can serve to alter the incentives of policy makers with regard to the use of trade policy instruments, and that the agreement could be designed in such a way that policy makers would have incentives to enter into it.

These environments can be illustrated at a general level with the aid of a simple twocountry three-stage game structure. Indexing countries by $j \in\{1,2\}$ and goods by $i \in\{1, \ldots, M\}$, let $\bar{x}_{j}$

19 This is not to say that I will ignore coordination problems completely, since the issue of coordination will arise in attempts to implement international trade agreements as I have defined them when there are multiple equilibria. But I will not consider pure coordination problems.

${ }^{20}$ By equating international trade agreements with regimes in which enforcement mechanisms are required, I do not mean that $I$ will restrict my attention only to a body of literature that is concerned with enforcement of trade agreements, but rather that I will restrict my attention to a literature that illuminates various aspects of trade agreements which share this structure.

${ }^{21}$ In focussing on the economic aspects of international trade agreements, I am ignoring potentially important non-economic effects of trade agreements associated with political/national security issues. 
denote the $1 \mathrm{xM}$ vector of country j's production, $\bar{y}_{j}$ the $1 \mathrm{xM}$ vector of country j's consumption, and $\bar{\tau}_{j}$ the $1 \mathrm{xM}$ vector of country j's trade taxes. Let $w_{j}\left(\bar{\tau}_{j}, \bar{\tau}_{\backslash j}\right)$ denote country j's objective function, assumed globally concave in $\bar{\tau}_{j}$ and depending also on $\bar{\tau}_{\backslash j}$, the $1 \times \mathrm{xM}$ vector of trade taxes set by $j$ 's trading partner. ${ }^{22}$

The first environment described above, in which the important strategic interaction is across governments in their trade policy choices, is represented by the following timing of moves in this three-stage game: First governments choose trade taxes; then production decisions are made; and finally consumption occurs. In this environment two extreme situations can be compared, one corresponding to the absence of an international trade agreement, and the other to the presence of a trade agreement which achieves perfect cooperation. Under the first regime. governments set trade taxes simultaneously to maximize their individual objective functions. Under the second regime. governments set trade taxes jointly to maximize a weighted sum of their objective functions. In each case, I wish to consider the subgame perfect equilibrium of the associated three-stage game. ${ }^{23}$

The question of whether there are potential gains from an international trade agreement in this environment can then be posed by asking whether the equilibrium absent such an agreement is Pareto efficient. If it is, then there can be no Pareto gains from a trade agreement. If it is not, then such gains may be possible. ${ }^{24}$ Denoting by $\bar{\tau}_{j}^{N}$ and $\bar{\tau}_{\backslash j}^{N}$ the $1 \times M$ vector of Nash tariffs selected by country $j$ and the $1 \mathrm{xM}$ vector of Nash tariffs selected by $j$ 's trading partner, respectively, in the subgame perfect equilibrium of the three-stage game when no trade agreement is present, the necessary and sufficient conditions for this equilibrium to be Pareto optimal are

\footnotetext{
22 By country $\mathrm{j}$ 's objective function I mean the objective function of the government of country $\mathrm{j}$ when setting trade policy, which may or may not correspond to social welfare. Similarly, 1 am examining the potential gains from the introduction of international rules evaluated with reference to government objective functions.

${ }^{23}$ For purposes of discussion at this point, I will assume that such an equilibrium exists and is unique, and that the equilibrium trade taxes are non-prohibitive. Non-uniqueness would introduce additional coordination issues of the kind I am not concerned with here, while the possibility of prohibitive equilibrium tariffs would unnecessarily complicate the conditions for Pareto optimality discussed below.

${ }^{24}$ Posing this question becomes considerably more complicated when there are more than two countries in the world and if gains from agreements among a subset of countries are considered.
} 
simply $W_{\tau_{\backslash j}}^{j}\left(\bar{\tau}_{j}^{N}, \bar{\tau}_{\backslash j}^{N}\right)=\overline{0}$ for $j \in\{1,2\}$. These conditions say that the trade tax equilibrium absent an international trade agreement will be Pareto efficient if and only if each country's equilibrium trade tax choices impose at the margin no externalities on its trading partner. ${ }^{25}$ Thus, in this first environment, the gains that come with an international trade agreement stem from internalizing the externalities that each country would impose on its trading partners in the absence of such an agreement through its equilibrium trade tax choices. One mechanism through which these externalities could be transmitted is the terms-of-trade effects of trade policy intervention. This is the mechanism that arises in all of the formal economic modeling of international trade agreements in this environment of which I am aware, and it is the mechanism present in each of the formal models of this environment reviewed below. ${ }^{26}$

The second environment described above, in which the important strategic interaction is between a government and its private agents, can be represented by a different timing of moves in the three stage game: First production decisions are made; then governments set trade taxes; and finally consumption decisions are made. Under this timing and in the absence of an international trade agreement, governments may face constraints in their ability to set desired tariffs due to their inability to commit prior to the decisions of producers. In this case, the role and potential impact of an international trade agreement depends in part on whether or not the

\footnotetext{
${ }^{25}$ Throughout this discussion I assume that international income transfers are feasible in the context of an international trade agreement. Where such transfers are not feasible, the scope for Pareto improving trade agreements can be reduced if there is no mechanism by which each country can be compensated for its tariff reductions. In the two country case considered above, this issue arises when countries are asymmetric (see, for example, Johnson, 1953-54 or Kennan and Riezman, 1988). On the general importance of international income transfers in reaching efficient outcomes in trade policy negotiations, see Kowalczyk and Sjostrom (1994).

${ }^{26}$ This is true both of models that assume trade taxes are set to maximize national welfare as, for example, in Dixit (1987) and of models in which trade taxes are chosen with political objectives in mind as, for example, in Grossman and Helpman (1993). This is not to say that terms-of-trade effects, or more generally world price effects, are the only possible mechanism through which these externalities can be transmitted. In the case of government export subsidies arising from strategic "rent-shifting" motives (Brander and Spencer, 1985), the positive externality imposed by each exporting government's subsidy on importers would come through the terms-of-trade effect, but the negative externality imposed by each exporting government's subsidy on each other exporting government would be composed of both a terms-of-trade effect and a market share effect (see also Robinson, 1947, for a discussion of employment effects as a possible transmission mechanism). But terms-oftrade effects are the only mechanisms that have been studied in a formal economic model of international trade agreements. See, for example, Yarbrough and Yarbrough (1992) for a broader interdisciplinary approach to this issue.
} 
timing of moves is altered with the introduction of such an agreement. If it is not, then an agreement can be counter-productive, a point made by Kehoe (1989) in the context of a twocountry two-period optimal capital/labor taxation problem. Intuitively, when government commitment with regard to the private sector is infeasible, the behavior of each government absent an agreement may constrain their ability to act opportunistically relative to their own private sectors, and may thus serve as a partial commitment device which is lost under an agreement. ${ }^{27}$ If the timing is altered by the agreement, and in particular if a trade agreement allows governments to move first, before producers, then whatever partial commitment might have been provided by government behavior absent the agreement is now obviated by the provision of full commitment under the agreement, and any gains from the agreement within the first environment outlined above would be realized as well. A second literature which I discuss below has considered formally the benefits of government commitment in trade policy, and has appealed informally to the potential role that international trade agreements could play in providing this commitment, i.e., in altering the timing of government decisions relative to the private sector.

\subsection{Strategic Interaction Across Governments}

Of the two environments noted above, the one for which the role and design of international trade agreements has been most thoroughly developed in the literature is that of strategic interactions across governments. Here, international agreements can be designed to mitigate the unilateral incentives of each country to pursue beggar-thy-neighbor trade policies. This basic point was made by Scitovszky (1942), who described how the pursuit of unilateral interests could lead to an escalating tariff war and emphasized the need for enforcement mechanisms in any attempt to escape from the resulting dilemma. Imagining a first round of tariff retaliation triggered by the "rational behavior of a single country trying to maximize its

\footnotetext{
${ }^{27}$ A somewhat related point is made by McLaren (1994), who considers the possibility that a small country can be made worse off under an anticipated free trade agreement with a large country than it would be in an anticipated tariff war. This possibility occurs when future production requires irreversible investment in the present, and producers in the small country, correctly anticipating a free trade agreement with the large country, make irreversible investments tying their production to the large country market. By robbing the small country of its flexibility at the bargaining stage of the free trade agreement, the actions of decentralized producers undercut the small country's bargaining power, and may result in a trade agreement which makes the small country worse off than it would be in an anticipated tariff war.
} 
national welfare" through beggar-thy-neighbor tariff setting, Scitovszky continued:

When tariff walls have been erected all around, those who started the process will find some of their initial advantage gone; but they are also likely to find that they can improve their position by raising tariffs further, even if initially they made full use of their monopolistic position. As tariff walls rise, conferences on international trade may be called to arrest the process, which is obviously harmful to all concerned. Yet as long as it remains in the individual interests of each country separately to raise tariffs, such collective attempts are bound to be ineffectual if not backed by international sanctions... (Scitovszky, 1942, p. 377).

I will begin by reviewing the basic unilateral incentives to pursue beggar-thy-neighbor trade policies which, if pursued by all countries, can lead to a situation analogous to the Prisoner's Dilemma in which each is made worse off. ${ }^{28}$ I will do so in a simple partial equilibrium tariff-setting framework which builds on the framework developed in Bagwell and Staiger $(1990,1993 \mathrm{a}, 1993 \mathrm{~b}) .^{29}$ I consider a domestic (no ${ }^{*}$ ) and foreign $\left(^{*}\right)$ country, each endowed with $3 / 2$ units of a locally abundant good and $1 / 2$ unit of a locally scarce good, and each wishing to consume both goods symmetrically through trade. I will refer to the domestic (foreign) locally abundant good as good 1 (good 2). I take the demand functions in the two countries to be symmetric across products and countries, and assume that the demand for product $i$ is independent of the price of product $j \neq i$. Specifically, the demand functions for product $i \in\{1,2\}$ are given by $C\left(P^{i}\right)=\alpha-P^{i}$ and $C\left(P^{i^{*}}\right)=\alpha-P^{i^{*}}$ where $\alpha>0, P^{i}$ is the price of good $i$ in the domestic country and $\mathrm{P}^{*}$ is the corresponding price in the foreign country. Given the symmetry between the two countries, for any product i I will simply speak of "the exporting country" and "the importing country." Accordingly, let $\mathrm{P}_{x}^{\mathrm{i}}$ denote the price of good $\mathrm{i}$ in the exporting country and $P_{m}^{i}$ give the price of good $i$ in the importing country, with $\tau_{m}^{i}$ representing the (specific) import tariff levied on good $i$. It follows that $P_{m}^{i}=P_{x}^{i}+\tau_{m}^{i}$ for each good i provided that $\tau_{m}^{i}$ is non-prohibitive. The structure of the basic model is completed with the market clearing condition for each product $\mathrm{i}: 2=\alpha-\mathrm{P}_{\mathrm{x}}^{i}+\alpha-\left(\mathrm{P}_{\mathrm{x}}^{\mathrm{i}}+\tau_{\mathrm{m}}^{i}\right)$. Solving for equilibrium prices $\hat{\mathrm{P}}_{\mathrm{x}}^{\mathrm{i}}$

\footnotetext{
${ }^{28}$ Strictly speaking, the Prisoner's Dilemma refers to a simultaneous move two-person static game where each player has just two strategies to choose from (cooperate or defect). The (stage) games I consider below are similar in nature to the Prisoner's Dilemma in that mutual cooperation would be better for all than mutual noncooperation, but defecting when everyone else cooperates would be better still.

${ }^{29}$ Johnson (1953-54) was the first to illustrate the tariff reaction curves and Nash equilibrium of a tariff war in a formal setting, adopting a standard two-good two-country general equilibrium trade model for this purpose (see Dixit, 1987 for a recent general equilibrium treatment). I adopt a simple partial equilibrium trade model for clarity of exposition, but the basic points I will illustrate depend only on the properties of the model reminiscent of a Prisoner's Dilemma, and would be shared by any trade model possessing these general properties.
} 
and $\hat{\mathrm{P}}_{\mathrm{m}}^{\mathrm{i}}$ and the equilibrium import volume of good $\mathrm{i}$, denoted by $\hat{\mathrm{M}}^{\mathrm{i}}\left(\tau_{\mathrm{m}}^{\mathrm{i}}\right)$, and imposing symmetric tariffs across products, yields expressions for market-clearing export prices, import prices, and import volume for each good: $\hat{P}_{x}\left(\tau_{m}\right)=(\alpha-1)-\tau_{m} / 2 ; \hat{P}_{m}\left(\tau_{m}\right)=(\alpha-1)+\tau_{m} / 2 ; \hat{M}\left(\tau_{m}\right)=$ $1 / 2-\tau_{m} / 2{ }^{30}$ These expressions hold for tariffs in the range $\tau_{m} \in[0,1]$ with $\tau_{m}=1$ the prohibitive tariff level. For $\tau_{m} \geq 1$, the tariff is prohibitive $\left(\hat{M}\left(\tau_{m}\right)=0\right), \hat{P}_{x}\left(\tau_{m}\right)=\alpha-3 / 2$, and $\hat{P}_{m}\left(\tau_{m}\right)=\alpha-1 / 2$.

I can now define the government objective function. I will assume that each government sets tariffs to maximize the sum of producer surplus, consumer surplus, and tariff revenue, with a weight $\gamma$ on the producer surplus generated in its import-competing sector. If $\gamma=1$, then the governments simply maximize social surplus with their tariff choices. I interpret $\gamma>1$ as a reflection of political economy considerations. Such an objective function will emerge in a lobbying context where the import-competing industry lobbies the government with a schedule of payments associated with different tariff levels and the government then chooses tariffs to maximize a weighted sum of social surplus and lobbying contributions, provided that the lobby is "small" relative to the whole economy. Under this interpretation, the government's weight on lobbying contributions is $\gamma-1$ (see Grossman and Helpman, 1993, for this interpretation and its generalization to a multiple-lobby setting). ${ }^{31}$ The domestic country's welfare function is

$$
W\left(\tau_{m}, \tau_{m}^{*}\right)=\underbrace{q}_{\hat{P}_{m}\left(\tau_{m}\right)} C(P) d P+\underset{\hat{P}_{x}\left(\tau_{m}^{*}\right)}{q} C(P) d P+\gamma \int_{0}^{\hat{P}_{m}\left(\tau_{m}\right)} 1 / 2 d P+\int_{0}^{\hat{P}_{x}\left(\tau_{m}^{*}\right)} 3 / 2 d P+\tau_{m} \hat{M}\left(\tau_{m}\right),
$$

where $\tau_{\mathrm{m}}$ is the import tariff levied by the domestic country and $\tau_{\mathrm{m}}^{*}$ is the import tariff imposed by the foreign country. The welfare of the foreign country is defined in an exactly symmetric fashion.

Consider now the incentive of a government to impose a tariff. With primes denoting derivatives, the effects on government welfare of a small increase in the tariff for $\tau_{m} \in[0,1]$ are given by $d W\left(\tau_{m}, \tau_{m}^{*}\right) / d \tau_{m}=\hat{M}\left(\tau_{m}\right)\left[1-\hat{P}_{m}^{\prime}\left(\tau_{m}\right)\right]+\tau_{m} \hat{M}^{\prime}\left(\tau_{m}\right)+[(\gamma-1) / 2] \hat{P}_{m}^{\prime}\left(\tau_{m}\right)$. Three features are noteworthy. First, the marginal effect of an import tariff for the domestic country

\footnotetext{
${ }^{30}$ Here and throughout the rest of the chapter I use "hats" to refer to equilibrium values.

${ }^{31}$ Under this interpretation, the government's welfare function would also contain an additive constant term to adjust for its equilibrium share of the surplus from its relationship with the lobby (see Grossman and Helpman, 1993).
} 
is completely independent of the trade policy of the foreign country. This arises because I have assumed that demands are independent and have ruled out export taxes; it will imply that each country's optimal tariff is independent of the tariff choice of its trading partner. While in general this independence will not hold, there is no presumption as to the sign that the dependence would take (see, for example, Dixit, 1987). Thus, the independent case seems a reasonable one to consider. Second, $\hat{\mathrm{P}}_{\mathrm{m}}^{\prime}\left(\tau_{\mathrm{m}}\right)<1$, which simply reflects the fact that the government has the power to affect world prices through tariff policy. Consequently, a small import tariff would improve government welfare even if the government were concerned only with social welfare (even if $\gamma=1$ ). Third, even absent terms-of-trade effects (i.e., even if $\hat{\mathrm{P}}_{\mathrm{m}}^{\prime}\left(\tau_{\mathrm{m}}\right)=1$ ), the government would find it beneficial to impose a small import tariff as long as political economy motives are present (that is, provided $\gamma>1$ ). Finally, it is easily shown that $d W\left(\tau_{m}, \tau_{m}^{*}\right) / d \tau_{m}=\gamma / 4-3 \tau_{m} / 4$ for $\tau_{m} \in[0,1)$. It follows that $W\left(\tau_{m}, \tau_{m}^{*}\right)$ is concave in $\tau_{m}$ over the range of non-prohibitive tariffs. Thus, for any fixed $\tau_{\mathrm{m}}^{*}$, the government's optimal response is $\tau_{\mathrm{m}}=\gamma / 3$ provided that $\gamma / 3<1$, which requires the parameter restriction $\gamma<3$ that I maintain for the remainder of the discussion. ${ }^{32}$

Now suppose that both governments simultaneously select an import tariff, with each government seeking to maximize its own welfare in a one-shot game. Since each government's best-response tariff is independent of the tariff imposed by the other country, the Nash equilibrium of the this tariff game occurs when each government selects the import tariff given by $\hat{\tau}^{N}=\gamma / 3$. It is easily verified that $\mathrm{W}(\tau, \tau)$ is strictly decreasing in $\tau$ for $\tau \in((\gamma-1) / 2$, $\gamma / 3]$, and so the tariff game has the structure reminiscent of a Prisoners' Dilemma: both governments are better off when tariffs are set symmetrically at $\tilde{\tau} \equiv(\gamma-1) / 2$ and are monotonically made better off with any symmetric movement towards $\tilde{\tau}$; but in the Nash equilibrium they are led by the unilateral pursuit of beggar-thy-neighbor terms-of-trade effects to impose the higher tariff $\hat{\tau}^{N}$ and experience the consequent lower welfare.

Figure 1 illustrates this situation by depicting for the domestic country the social surplus from importing in the top left panel, the social surplus from exporting in the top right panel, and

32 If $\gamma \geq 3$, then the government's optimal tariff is driven by political considerations to be prohibitive, and there will be no gains from trade (as perceived by the government), and no role for international trade agreements. 
the politically weighted $(\gamma-1)$ import-competing producer surplus in the top center panel, for the case where $\gamma \in(1,3)$. Under symmetric tariffs set at $\tilde{\tau}$, these gains would be given by the area under the import demand curve and the tariff revenue $\left(m_{1} m_{2} m_{3}+m_{2} m_{3} m_{2} m_{5}\right)$, the area above the export supply curve $\left(x_{r_{2}} x_{3}\right)$, and the political benefit $\left(l_{0} l_{l}\right)$, respectively. Under the optimal tariff $\hat{\tau}^{N}$, the additional social gains from importing are given by the additional net tariff revenue collected from abroad minus the additional dead-weight loss imposed on the domestic country $\left(m_{s} m_{8} m \cdot m_{8}-m_{s} m_{s} m_{b} m_{9}\right)$, while the additional political benefits are given by $\left(l_{l} l_{2}\right)$. Facing the optimal tariff abroad, the reduction in the social gains from exporting are given by the additional net import taxes paid by exporters and the additional dead-weight loss imposed on the domestic country $\left(x_{2} x_{6} x_{5} x_{5}+x_{9} x_{1} x_{6}\right)$. Taken together, when both governments raise their tariffs from $\tilde{\tau}$ to $\hat{\tau}^{N}$, the losses in each country's export market outweigh the sum of the gains in its import market and its political market, with the net loss for each government amounting to the sum of the additional dead-weight loss across sectors minus the additional political benefits $\left(m_{s} m_{s} m_{6} m_{9}+x_{9} x_{1} x_{6}-l_{1} l_{2}\right)$.

The lower panel of Figure 1 depicts the domestic and foreign tariff reaction curves, with domestic indifference curves reflecting the relative government welfare rankings associated with reciprocal tariffs set at $\tilde{\tau}$, unilateral optimal tariff setting, and Nash equilibrium tariffs in the tariff game. Provided that the governments perceive any gains from trade (i.e., provided that $\gamma<3$ ), there will clearly be a role here for an international trade agreement that restrict tariffs to $\tilde{\tau}$, and rule enforcement will be a key implementation issue.

\subsection{Strategic Interaction between a Government and its Private Sector}

As described above, the second environment where the potential benefits of international trade agreements has been noted is one where the credibility of announced trade policy plans is in question. Often a government may be confronted with trade policy decisions that require commitment to a course of action that it might be tempted to reverse at a later date. When such dynamically- (or "time-") inconsistent policies are optimal, effective government intervention may hinge on a government's ability to make a credible commitment to announced policies. Where domestic institutions allow a high degree of discretion in trade policy, making credible commitments may be difficult unless international rules can provide the needed credibility. 
The idea that policy discretion might provide governments with an incentive to surprise the private sector, that this incentive to surprise could undermine the credibility of optimal government policies, and that adherence to policy rules might restore credibility and therefore lead to preferred outcomes, was introduced in the seminal paper by Kydland and Prescott (1977), which quickly had a major influence in macroeconomics and public finance (see Persson and Tabellini, 1990, for a survey of the theoretical literature on the issue of rules versus discretion in these fields). Ironically, despite the fact that the practical relevance of these ideas is almost surely more important for international trade policy, their impact on the international trade literature was virtually non-existent until relatively recently.

The pervasive importance of the issues raised by Kydland and Prescott in the context of trade intervention can be appreciated intuitively by observing that a necessary condition for an economic policy to be time-inconsistent is that the government pursuing the policy find itself in a second best (or worse) situation. But with trade intervention this condition will virtually always be met: If a government is forced to rely on trade intervention to achieve its policy goals, this is because it lacks other less distortionary instruments. This is the central conclusion to emerge from the literature on distortions and trade policy intervention (see, for example, Corden, 1984). In such an environment, unexpected trade policy actions can enlarge the set of policy instruments at the government's disposal, allowing it to move closer to the first best. This provides the government with an incentive to attempt to surprise the private sector with unexpected policies whenever it has sufficient discretion to do so. That is, with a sufficient degree of discretion, the optimal trade policy is bound to lack credibility, because it is almost surely time-inconsistent. When this is the case, and when domestic institutions are too weak to provide the desired commitment, international trade agreements could serve as a possible commitment device in interactions between a government and the private sector, and restore the credibility of the optimal trade policy.

This general theme or some variation on it runs through a number of papers in the international trade literature. I will illustrate the basic point by describing the results of Staiger and Tabellini (1987), who consider the credibility issues arising from the use of tariffs as a 
redistributive tool. ${ }^{33}$ They explore the use of tariffs to redistribute income from workers with low marginal utility of income to those with high marginal utility of income subsequent to a terms-oftrade shock. Specifically, workers can change sectors in response to a random terms-of-trade shock which lowers the world price of the imported good by an amount $\varepsilon$, but as a consequence of relocating a worker's marginal productivity falls by the fraction $1-\lambda$. In this setting, a termsof-trade shock can create a wage differential across sectors in the economy, with injured sector workers receiving in equilibrium a wage amounting only to the fraction $\lambda$ of the favored sector wage as long any workers actually leave the injured sector. Under such circumstances, a government might be tempted to use trade policy to reduce the wage differential between the two sectors. ${ }^{\text {.+ }}$

However, the wage differential will tend to persist even if the government intervenes with a trade policy designed to offset the terms-of-trade shock, provided that the intervention is fully anticipated by workers: Such intervention only serves to reduce the number of workers leaving the injured sector, with the wage differential unaffected as long as some exit from the injured sector occurs. $^{35}$ This property underlies the equilibrium combinations of sectoral wage differential and tariff depicted in Figure 2 as the locus $a b c$. Given the large tariff and associated distortions that must be introduced into the economy in order to achieve any redistributional effects (corresponding to the long horizontal portion of the locus $a b c$ in Figure 2), it follows that, in the model, the optimal trade policy response to a terms-of-trade shock will be free trade for a wide range of parameters. And under a system of "rules" and the implied timing of moves in the game between the government and the private sector (first the government sets tariff policy, then supply side decisions are made, and finally consumption decisions are determined), the

\footnotetext{
${ }^{33}$ Other papers focussing on credibility problems associated with the use of trade policy instruments include Carmichael (1987), Gruenspecht (1988), Lapan (1988), Staiger and Tabellini (1989, 1991, forthcoming), Maskin and Newbery (1990), Matsuyama (1990), Tornell (1991), Devereux (1993), Brainard (1994), and Mayer (1994).

34 Eaton and Grossman (1985) show that such a policy can be optimal ex-ante, in the sense that it can achieve some beneficial risk-sharing between risk averse individuals when insurance markets are incomplete. See Dixit (1989), however, for a challenge to this view.

35 With heterogeneous moving costs across workers, sectoral allocation decisions would not completely undo the redistributive impacts of anticipated tariffs, but would still diminish them, and the incentive to provide surprise protection and associated credibility problems are still present (see Staiger and Tabellini, forthcoming).
} 
optimal trade policy response to the terms-of-trade shock can be implemented.

But when free trade is the optimal response, it will not be time-consistent and thus, absent rules, i.e., if the government is endowed with sufficient policy discretion so that its tariff choice comes after supply side decisions are made, the optimal tariff policy can not be implemented. The problem is that while small amounts of anticipated protection can not affect the distribution of income, small amounts of unanticipated protection can do so, since labor cannot reallocate to offset the wage effects of such protection. This provides the government with an incentive to surprise the private sector with unannounced protection.

Figure 2 illustrates this incentive to surprise together with the time-consistent solution when import-competing sector $y$ faces injury from a terms-of-trade shock. A family of government indifference curves defined over the sectoral wage differential $\mathrm{W}^{\mathrm{y}} / \mathrm{W}^{\mathrm{x}}$ and tariff $(1+\tau)$ exists for each level of the tariff expected by the private sector, $\tau^{e}$ (since this determines the intersectoral allocation of labor). Consider the government's tariff choice facing a private sector that anticipates free trade. The government indifference curve corresponding to $\tau^{\mathrm{c}}=0$ and passing through point $a$ on the equilibrium locus $a b c$ is flat at $\tau=0$ and upward sloping for $\tau>0$ in a neighborhood of $a$, reflecting the tradeoff between the benefits of redistributing income toward injured-sector workers and the distortionary costs of the tariff. However, with the labor allocation (and production plans) from the first stage based on $\tau^{\mathrm{e}}=0$ taken as a bygone when the government sets tariffs in the second stage, the locus of feasible points as perceived by the government is given not by $a b c$ but by the upward sloping dashed line labeled as $\tau^{\mathrm{e}}=0$ : As noted above, the government can increase $\mathrm{W}^{\mathrm{y}} / \mathrm{W}^{\mathrm{x}}$ towards unity by imposing an unanticipated tariff. This gives the government an incentive to surprise a private sector that was anticipating free trade by imposing an unexpected tariff which would move the economy to a point such as $d$ in Figure 2 , where a government indifference curve is tangent to the $\tau^{e}=0$ locus. Of course, anticipating these government incentives through backward induction, the private sector will not expect free trade in equilibrium, and a point such as $d$ in Figure 2 cannot be an equilibrium outcome of the game. The (time-consistent) equilibrium outcome will occur at a point such as $z$ on the $a b c$ locus in Figure 2, where the tariff is fully anticipated and the government has no further incentive to surprise.

The "discretionary" outcome is clearly inferior to the "rules" outcome of laissez faire, 
because under the former regime the government's tariff policy distorts production and consumption decisions while achieving no distributional benefits. Hence, if an international trade agreement can supply a government with such trade policy rules where the government would lack them otherwise, then the agreement will serve a valuable function. Again, however, as with the previous case, there is a question of how these rules could be enforced. This is the question to which I now turn.

\section{Enforcement of International Trade Rules}

In this section I review the literature on enforcement issues that arise with international trade agreements. This literature begins with the view that international trade agreements must be self-enforcing, and proceeds to examine the possible role played by international dispute settlement procedures such as those in Article XXIII of GATT. I will proceed by first laying out the basic limits imposed by the restriction that an agreement must be self-enforcing, and then discussing and interpreting a number of papers that have attempted to shed light on the role of international dispute settlement procedures in this context.

\subsection{Repeated Interaction and Enforcement}

Whether the economic benefits of international trade agreements stem from their potential to limit the temptation to pursue beggar-thy-neighbor trade policies or their potential to broaden the range of trade policies that are credible with respect to each country's private sector, the temptations for unilateral trade policy choices do not simply go away once an agreement is in place. Instead, international agreements must be constructed so that these temptations remain in check.

Consider, for example, the beggar-thy-neighbor trade policies which underlie Figure 1. It is clear from the situation depicted in Figure 1 that each country could gain if both agreed to adhere to an international rule that "bound" tariffs at $\tilde{\tau}$. But it is equally clear that each country would have a unilateral incentive to cheat on such an agreement, and move to its tariff reaction curve. This raises a crucial question that confronts governments when they attempt to implement a trade agreement in this situation: By what mechanism is the tariff binding to be enforced? Since countries trade repeatedly through time, a natural possibility is to use the threat of future punishments to deter violations of an agreement. As noted in Section 2 above, in a general sense, this is precisely what countries do in practice: Such enforcement procedures are codified 
in national law, e.g., section 301 of the 1974 Trade Act in the United States, and in international agreements, e.g., the dispute settlement procedures in GATT. I will turn to the possible design of these enforcement mechanisms and the literature concerned with them in a moment. Here I simply illustrate that the effectiveness of enforcement mechanisms may be limited by the severity of credible (e.g., subgame perfect) threats and that, when this is the case, governments may find that their ability to implement international trade agreements is constrained by their temptation to cheat. Indeed, when enforcement issues are important it will be the incentive constraints that determine the equilibrium trade barriers.

To illustrate this basic point, I consider an infinitely repeated tariff game along the lines of Bagwell and Staiger (1993a), which is defined by the infinite repetition of the one-shot tariff game described in Section 3.1. In each period the countries observe all previous import tariff selections and simultaneously choose import tariffs. Let $\delta \in(0,1)$ denote the discount factor between periods. $^{36}$ For illustrative purposes, I consider subgame perfect equilibria in which (i) symmetric stationary tariffs no lower than $\tilde{\tau}$ are selected along the equilibrium path, meaning that in equilibrium the two countries select the same import tariff in each period, and (ii) if a deviation from this common tariff occurs, then in the next period and forever thereafter the countries revert to the Nash equilibrium tariffs of the one-shot tariff game given by $\hat{\tau}^{N} .^{37}$

In this repeated tariff game, countries have the possibility of supporting a "cooperative" tariff $\tau^{c}$, with $\tau^{c}<\hat{\tau}^{N}$, since any attempt to raise the current-period tariff will under the agreement

36 The infinitely repeated tariff game with discounting at rate $\delta$ can equivalently be thought of as a repeated tariff game with a constant hazard rate that the game will continue. In the latter case, $\delta=h e^{-r L}$ where $h$ is the hazard rate, $r$ is the pure interest component of the discount factor, and $L$ is the period length. In the former case, $h$ would be one. Repeated tariff games with a fixed and finite termination, on the other hand, may preclude opportunities for tacit cooperation to be supported as a subgame-perfect equilibrium, although see Dixit (1987) for the case in which there are multiple static Nash equilibria, and Jensen and Thursby (1984) who consider incomplete information and also alternative equilibrium concepts.

${ }^{37}$ Subgame perfection allows more severe punishments than the infinite Nash reversion that I adopt here (see Abreu. 1986, 1988), and with more severe punishments comes greater liberalization. Here I adopt infinite Nash reversion to illustrate the main ideas, but more severe punishments could easily be accommodated. For example, if export taxes were introduced into the model set out above (see, Bagwell and Staiger, 1990), then autarky could be supported as a Nash equilibrium, and infinite reversion to autarky would provide an optimal punishment in the sense of Abreu. Also, see Furusawa (1994) for an interesting treatment of asymmetries across countries. 
lead in all future periods to a retaliatory (one-shot Nash) tariff from the trading partner. ${ }^{38}$ Intuitively, an agreement to bind tariffs at $\tau^{c}$ can be enforced if the one-time incentive to cheat is sufficiently small relative to the discounted future value of avoiding the "trade war" that would be triggered as a consequence. Put differently, for enforcement to present a relevant constraint on the feasible trade agreements in this setting, there must be significant one-time gains in defecting from $\tilde{\tau}$, and the cost of future punishments must be discounted heavily. In fact, for a given rate of time preference, these two conditions are related, and reflect a common underlying factor: The length of each period in the repeated tariff game must be sufficiently long. The period length, in turn, can be thought of as reflecting the length of time it takes to observe the trade policies of one's trading partner and respond. ${ }^{39} 40$

To formalize this intuition, I first examine the temptation a country has to cheat. Given the symmetry of the model, I will do so from the domestic country's perspective. For a fixed cooperative tariff $\tau^{\mathrm{c}}<\hat{\tau}^{\mathrm{N}}$, and given the class of subgame perfect equilibria I consider, if a country deviates and selects $\tau \neq \tau^{c}$, then it will deviate to its best-response one-shot Nash tariff,

\footnotetext{
${ }^{38}$ Throughout the remainder of the chapter I will refer to tariffs stemming from international trade agreements as "cooperative" tariffs, whether or not the international agreements are modeled as cooperative games (i.e., requiring an external enforcement mechanism) or non-cooperative games (i.e., self-enforcing) as in the present example (See Friedman, 1986, Ch 1).

39 This statement is correct within a setting of perfect monitoring, i.e, where the period's tariff choices become common knowledge at the end of each period. For important qualifications on the role of interest rates, information lags, and response times in a setting of imperfect monitoring, see Abreu, Milgrom and Pearce (1991).

40 In this regard, there is ample historical and anecdotal evidence that response times in trade disputes are often lengthy, and sometimes exceedingly so. A detailed historical account of a number of major trade wars can be found in Conybeare (1987). A recent and instructive example is that of the Chicken War (see also Talbot, 1978). This trade war between the United States and the European Community (EC) effectively began in July 1962 when EC regulations associated with the implementation of the Common Agricultural Policy brought to a halt the rapid increases in U.S. exports of frozen chickens into the EC market. For the next year the United States was involved with the EC in a debate over the degree of discrimination against U.S. chicken exports. The United States then requested compensation from the EC under an agreement reached as part of the Dillon Round, but failed to come to agreement with the EC over the amount of compensation it should receive. Finally, in September 1963, both sides agreed to submit the dispute to a special GATT tribunal. The tribunal found U.S. complaints to be justified and authorized the United States to withdraw concessions by an equivalent amount, which the United States subsequently did on January 7,1964, 18 months after the original EC actions had taken effect.
} 
$\hat{\tau}^{\mathrm{N}} .41$ Thus, the domestic country's gain in cheating is $\Omega\left(\tau^{c}\right) \equiv W\left(\hat{\tau}^{\mathrm{N}}, \tau^{c}\right)-W\left(\tau^{c}, \tau^{c}\right)$. When a country cheats, however, it triggers a "trade war," the cost of which must also be considered. The one-period value to the domestic country in avoiding a trade war and sustaining the cooperative tariff is $\omega\left(\tau^{c}\right) \equiv W\left(\tau^{c}, \tau^{c}\right)-W\left(\hat{\tau}^{N}, \hat{\tau}^{N}\right)$. Then the cost to the domestic country associated with cheating is $\mathrm{V}\left(\delta, \tau^{c}\right) \equiv \delta \cdot \omega\left(\tau^{c}\right) /(1-\delta)$, since once a country defects and selects a high import tariff, cooperative tariffs are thereafter replaced by the higher one-shot Nash tariffs. This allows the domestic government's incentive constraint, which requires that the benefit of cheating be no greater than the discounted future value of cooperation that would be forfeited as a consequence, to be written as $\Omega\left(\tau^{c}\right) \leq V\left(\delta, \tau^{c}\right)$. An identical (redundant) incentive constraint holds for the foreign country. Any cooperative tariff $\tau^{\mathrm{c}}$ that satisfies this incentive constraint can be supported in a subgame perfect equilibrium of the repeated tariff game.

Now consider the "most-cooperative" tariff, $\hat{\tau}^{c}$, which I define as the smallest tariff equal to or above $\tilde{\tau}$ that satisfies the incentive constraint. The determination of the most-cooperative tariff can be simply illustrated by Figure 3, which depicts $\Omega\left(\tau^{\mathfrak{c}}\right)$ and $V\left(\delta, \tau^{\mathfrak{c}}\right)$ as a function of $\tau^{\mathfrak{c}}$. Observe in Figure 3 that $\Omega\left(\tau^{\mathfrak{c}}\right)$ is monotonically decreasing in $\tau^{\mathrm{c}}$ for $\tau^{\mathrm{c}}<\hat{\tau}^{\mathrm{N}}$, and is flat and equal to zero at $\hat{\tau}^{\mathrm{N}}$. This reflects the fact that a government gains less in deviating from a cooperative tariff $\tau^{\mathrm{c}}$ the closer is that tariff to the one-shot Nash tariff $\hat{\tau}^{\mathrm{N}}$, and gains nothing in deviating at (or around) $\hat{\tau}^{\mathrm{N}}$. On the other hand, Figure 3 depicts $V\left(\delta, \tau^{\mathrm{c}}\right)$ as equal to zero at $\hat{\tau}^{\mathrm{N}}$, monotonically decreasing in $\tau^{\mathfrak{c}}$ for $\tau^{\mathrm{c}}>\tilde{\tau}$, and flat at $\tau^{\mathfrak{c}}=\tilde{\tau}$. This reflects the fact that the gains from avoiding a trade war decline to zero as the tariffs stipulated in the agreement rise from $\tilde{\tau}$ and approach the level that would be chosen in a trade war anyway, and that, at $\tilde{\tau}$, a small symmetric increase in cooperative tariffs would have no impact on government welfare (this is just the first-order conditions that defines $\tilde{\tau}$ ). Since the government incentive constraint requires that $V\left(\delta, \tau^{c}\right)$ be no less than $\Omega\left(\tau^{c}\right)$, Figure 3 implies that the range of tariffs $\tau^{c} \in\left[\hat{\tau}^{c}, \hat{\tau}^{N}\right]$ are supportable as subgame perfect equilibrium tariffs, with the most-cooperative tariff $\hat{\tau}^{\mathrm{c}}$ defined

\footnotetext{
4I Note that the choice of defection tariff, while generally a move to one's tariff reaction curve, is made trivial in the particular model I am considering by the lack of slope in the tariff reaction curves. More generally, a government's defection tariff would depend on the equilibrium tariff of its trading partner.
} 
where the incentive constraint holds with equality. ${ }^{42}$

\subsection{Dispute Settlement Procedures}

I now turn to the literature that is directly related to the role and design of dispute settlement procedures. This literature takes as its starting point the presumption that enforcement issues place a binding constraint on international trade agreements, and models trade agreements as repeated games played between or among countries, as in the case of the determination of $\hat{\tau}^{c}$ illustrated in Figure 3. It then asks what the role of an explicit dispute settlement procedure might be in facilitating liberalization under the agreement.

One view is that dispute settlement procedures simply serve to codify the kinds of trigger strategies supporting the most-cooperative tariff illustrated in Figure 3, and thereby help to eliminate the well-known coordination problems that could otherwise plague countries in their attempts to choose among the multiplicity of cooperative tariffs supported by such strategies, i.e., any tariff between $\hat{\tau}^{\mathrm{N}}$ and $\hat{\tau}^{\mathrm{c}}$ in Figure 3. It seems plausible that dispute settlement procedures do provide such a coordination device, but as discussed in section 2 it seems less plausible that this is all they do: Surely this view abstracts from many complications that are likely to be important in the actual workings of any mechanism for enforcement of international agreements. Moreover, even a minimal dispute settlement procedure that simply codified the rules of enforcement is likely to change as additional complications are considered. The literature highlights a number of these complications, and considers how dispute settlement procedures might look in their presence.

While an interpretation of the model underlying Figure 3 is that trade policies are perfectly and costlessly observable with a (one period) lag, in practice this perfect, costless observability is unlikely. Dispute settlement procedures may therefore play an important role in gathering and disseminating information. A first attempt to capture this information role is contained in Hungerford (1991), who depicts the central enforcement problem faced by countries

\footnotetext{
${ }^{42}$ In the formal model provided in the text, $\Omega\left(\tau^{c}\right)$ will be convex while $V\left(\delta, \tau^{c}\right)$ will be concave, as depicted in Figure 3. Thus, the two curves will intersect at most once over the range $\tau^{c} \in\left[\tilde{\tau}, \hat{\tau}^{N}\right)$. More generally, if the two curves intersect in multiple places, then $\hat{\tau}^{c}$ will correspond to the lowest such intersection (provided that $\Omega\left(\tau^{\mathrm{c}}\right)$ lies above $\mathrm{V}\left(\delta, \tau^{\mathrm{c}}\right)$ at $\tilde{\tau}$ ). Also, consideration of alternative punishments with more or less severity would act to shift $\mathrm{V}\left(\delta, \tau^{\mathrm{c}}\right)$ up or down in Figure 3 accordingly.
} 
attempting to sustain international trade agreements as one of monitoring. In a setting adopted from Green and Porter's (1984) analysis of industry cartel behavior when price information is imperfect, Hungerford considers a two-country world in which movements in the terms of trade cannot readily be assigned to their underlying causes. These causes may either be random and unobserved shocks to supply and demand, or the beggar-thy-neighbor use of unobserved nontariff barriers by one's trading partner. Tariffs, on the other hand, are taken to be observable, and are set at (externally enforced) GATT-bound levels.

Hungerford's point is essentially this. One way for countries to reduce their non-tariff barriers below the one-shot Nash levels in this setting is to accept the unobservability of nontariff barriers and to condition retaliation on movements in observable variables which (imperfectly) reflect information about these non-tariff barriers. ${ }^{43}$ One such variable might be the level of exports. ${ }^{44}$ If this approach to enforcement were adopted, and if tariffs were the designated instrument of retaliation, the role of a dispute settlement procedure would be minimal, simply providing a coordination device for selecting punishment strategies and granting exceptions from GATT tariff bindings to carry out the agreed-upon punishments. Consider first this minimal version of a dispute settlement procedure. The punishment strategies are analogous to those suggested by Green and Porter for collusive firms, and will lead to the analogous outcome: Countries agree to switch temporarily from their GATT-bound tariff levels to one-shot

43 An alternative would be for countries simply to enter into trade agreements covering only those trade policy instruments which they can observe, e.g., tariffs (see Copeland, 1990).

44 While Hungerford (1991) focusses on movements in the terms of trade to trigger punishments, Riezman (1991) has shown that no trigger strategy equilibrium can exist when terms-of-trade movements are the trigger. Intuitively, at the equilibrium, each country must be deterred from deviating to a slightly higher trade barrier by the increased likelihood that a punishment phase will be triggered as a result. Under a terms-of-trade trigger, to keep the incentives of each country in check, punishments must be triggered whenever either country's terms of trade drops below a critical level. In other words, countries must adopt a terms-of-trade band around the nointervention no-shock terms of trade, and must revert to a punishment phase whenever the terms of trade falls outside this band. But a slightly higher trade barrier then has an ambiguous effect on the likelihood that a punishment phase will be triggered, since it will increase the likelihood that a country's terms of trade falls above the upper limit of the band, but will decrease the likelihood that a country's terms of trade will fall below the lower limit. Riezman shows that each country can not simultaneously perceive that the likelihood of a punishment phase is increased by a small increase in its trade barrier, and thus that no trigger-strategy equilibrium can exist under terms-of-trade triggers. For this reason, I describe Hungerford's results on dispute settlement procedures under an export-trigger interpretation (which does not suffer from this problem provided that offer curves are elastic over the relevant range). 
Nash tariffs (engage in trade wars of a pre-specified duration) when either country's exports fall unexpectedly below a cut-off level as a way to mitigate each country's incentives to secretly defect from the agreed-upon non-tariff barrier choices. The non-tariff barriers are themselves set at the lowest non-negative level that maintains incentive compatibility under these strategies.

Now consider an alternative depiction of dispute settlement procedures that captures some of the aversion to retaliation that, as described in Section 2, seems to characterize actual procedures. While the minimal procedure outlined above might correspond roughly to the "rule integrity" forces operating in actual dispute settlement procedures, Hungerford attempts to capture the counterbalancing "negotiation/conciliation" forces by adding the requirement that a costly and imperfectly-informative (but instantaneous) investigation must take place as a prerequisite to retaliation. This tends to reduce the frequency of trade wars, a change which on the surface might appear to be for the better since trade wars are never triggered by a defection from agreedupon low levels of non-tariff barriers anyway, always caused instead by random shocks to supply and demand.

And indeed, if the investigation required by the dispute settlement procedure could perfectly discern whether or not a defection had taken place, and if retaliation could be conditioned on this information, then the fact that information gathering is costly might justify the use of such investigations periodically: The information gathered could be used to avoid otherwise costly trade wars without undercutting the incentives to keep non-tariff barriers low. That is, each time a trade war would have erupted under the minimal dispute settlement procedures outlined above, this alternative dispute settlement procedure would launch a costly investigation instead, to reveal whether or not defections from the agreed-upon non-tariff barrier levels had occurred. A trade war would only erupt if indeed a defection had occurred. Since defections never do occur in equilibrium, the benefits of such a dispute settlement procedure would be the complete elimination of costly trade wars (without interfering with the incentive effects of the threat of trade wars), and these benefits would have to be weighed against the cost of periodic investigations. ${ }^{45}$

\footnotetext{
${ }^{45}$ There is still the important question of why an international (as opposed to domestic) institution would be required to carry out this information gathering function.
} 
But if the information gathering functions of the dispute settlement procedure are weak as Hungerford assumes (in fact, under Hungerford's depiction, they are essentially uninformative), the trade wars themselves are necessary if unfortunate episodes required to maintain rule integrity, as it is the periodic outbreak of such wars that prevents countries from cheating on the agreement. Consequently, institutions that interfere with their occurrence and do no more will be counter-productive. Thus, in this case, there will be a tradeoff between allowing low-tariff episodes to be interrupted periodically by costly trade wars and the ability to maintain low levels of non-tariff barriers. This is a crucial point, since it provides a formalization of the tension that has been noted in the design and workings of actual dispute settlement procedures. That is, the rule integrity and negotiation/conciliation forces operating in such procedures may work at cross purposes, and especially so if the latter do not serve an important information gathering role.

Ludema (1990) also explores the apparent aversion to retaliation exhibited by dispute settlement procedures. He considers the emphasis that has been observed on negotiated settlements of the dispute that are agreeable to both sides. Ludema models the dispute settlement procedure as providing a forum for renegotiation after a dispute erupts. Formally, ascertaining the effect of such a dispute settlement procedure amounts to comparing the most-cooperative tariff in an infinitely repeated tariff game across two different scenarios: One in which threatened punishments need be subgame perfect (a minimal dispute settlement procedure which serves only to coordinate countries on the equilibrium punishments, and does so at the outset of the agreement) and the other in which threatened punishments must be "renegotiation-proof," i.e., they must be expected to arise from the renegotiation process that occurs as a result of a dispute settlement procedure that provides on-going communication channels. Ludema chooses a definition of renegotiation-proof equilibria due to Pearce (1987), which requires that a punishment equilibrium be Pareto optimal on the set of subgame perfect equilibria that rely on no punishments worse than themselves. Not surprisingly, by providing a forum for renegotiation once a dispute has begun, the dispute procedure diminishes the deterrent effect of threatened punishments, and so dispute settlement procedures as envisioned by Ludema can only impede the maintenance of low tariff levels. In terms of Figure 3, the renegotiation channels provided by a dispute settlement procedure would shift $\mathrm{V}\left(\delta, \tau^{\mathrm{c}}\right)$ down. But the result should be thought of not as a case against maintaining dispute settlement procedures, but rather as an inevitable 
consequence of the communication channels that must exist if a dispute settlement procedure is to perform its other, presumably cooperation-enhancing, functions (e.g., monitoring).

A possibly trade-liberalizing role for dispute settlement procedures is considered by Kovenoch and Thursby (1992). They view a workable dispute settlement procedure as necessary to induce countries to feel an "international obligation" to upholding the agreement, a point often emphasized by legal scholars (such as Hudec, 1990, and Jackson, 1989) and somewhat related to Dam's (1970) function (3), as enumerated above. That is, according to Kovenoch and Thursby, the existence of a dispute settlement procedure can endow countries with a sense of "obligation" to the agreement, and this in turn can relax the incentive constraints which restrict the degree of tariff liberalization attainable. For example, if violating such an international obligation imposed a fixed "psychic" cost on the violator in the period of defection and in all subsequent periods, and if this cost were in addition to all costs of changes in future actions that were induced by the defection, then a dispute settlement procedure would have the effect of inducing a downward shift of $\Omega\left(\tau^{c}\right)$ and an upward shift of $V\left(\delta, \tau^{c}\right)$ in Figure 3, resulting in a lower sustainable tariff level.

The notion of international obligation, and the role that dispute settlement procedures may play in instilling such a sense of obligation in parties to an international agreement, may well be an important dimension of the benefits of a "well-working" dispute settlement procedure. A difficulty with this approach is that what is meant by "well-working" becomes somewhat tautological (whatever instills countries with this sense of international obligation). Still, it does point to one reason why dispute settlement procedures that are generally approved of by all parties to the agreement may facilitate trade liberalization under the agreement. This seems to provide a possible starting point for evaluating alternative enforcement mechanisms, such as unilateral retaliation occurring outside the dispute settlement procedures of the agreement, as has occurred for example when the United States has retaliated under its "section 301" authority without abiding by GATT dispute settlement procedures (see, for example, McMillan, 1990, Bayard and Elliott, 1992, and Finger and Fung, 1993).

Finally, while the debate on the implications of ignoring GATT dispute settlement procedures and relying instead on alternative enforcement mechanisms is often framed in the context of multilateral versus unilateral or bilateral approaches to dispute resolution (see for 
example Bhagwati, 1991, on "aggressive unilateralism"), the papers reviewed thus far have not formally considered the possibly unique advantages of a multilateral dispute settlement procedure over a bilateral procedure. Indeed, since these papers all adopt a two-country setting, they can make no distinction between the two. This distinction is the focus of a recent paper by Maggi (1994).

Maggi identifies two broad categories of gains from a multilateral enforcement mechanism over a web of bilateral mechanisms. The first gain arises in the presence of local "imbalances of power," defined by Maggi as a situation where different countries stand to lose different amounts from a trade war, with the more "powerful" countries standing to lose less. In such circumstances, the exchange of enforcement power that can be affected under a multilateral dispute settlement procedure can serve to support lower tariffs than would be possible under purely bilateral procedures. Specifically, in a multilateral enforcement mechanism, each country can serve as a third-party enforcer of low tariffs in bilateral relationships where it is "strong" in exchange for receiving third-party enforcement from others in bilateral relationships where it is "weak." Purely bilateral enforcement mechanisms cannot effect this "exchange" of enforcement power. $^{46}$ A second kind of gain from multilateral enforcement mechanisms identified by Maggi is associated with the "aggregation" of enforcement power: Since tariffs levied by different governments on the same imported product tend to be strategic complements (see, also, Bagwell and Staiger, 1993b), a multilateral enforcement mechanism which has many governments joining in the punishments can lead to proportionately more severe punishments than would be forthcoming under bilateral enforcement procedures.

When either local imbalances of power or strategic tariff complementarities are present, Maggi shows that a multilateral dispute settlement procedure is necessary to achieve the gains from exchange and aggregation of enforcement power. Hence, the monitoring function of the dispute settlement procedure is once again emphasized, but now it is the dissemination of information to third parties that is the crucial service provided by the dispute settlement

\footnotetext{
${ }^{46}$ This point is reminiscent of the pooling of incentive constraints analyzed by Bernheim and Whinston (1990) in the case of collusive firms competing across distinct markets.
} 
procedure. $^{47}$

In summary, the literature I have reviewed in this section has been motivated by the opposing forces that work to shape dispute settlement procedures in practice. These sometimes contradictory forces present a substantial challenge for developing a coherent picture of the role of dispute settlement procedures in international trade agreements, but such a picture is a necessary precursor to a serious evaluation of the costs and benefits of alternative enforcement mechanisms. At the same time, the literature illustrates the subtle issues involved in the design of dispute settlement procedures and suggests that, as a practical matter, enforcement capabilities are likely to be imperfect. As a result, the nature and performance of intentional trade agreements are likely to reflect the limitations imposed by weak enforcement capabilities, a theme that recurs in much of the literature on other dimensions of trade rules to which I now turn.

\section{The Process of Reciprocal Trade Liberalization}

A striking feature of the multilateral trade liberalization that has occurred since 1947 is just how long it has taken. While the extent of liberalization achieved is certainly remarkable for the depth in the reduction of trade barriers, the process by which this liberalization has occurred through eight "rounds" of negotiation over a fifty year period is no less remarkable for its gradualism. There are two dimensions of this observation that pose a challenge to the literature on international trade agreements that I have reviewed thus far. The first is that the rounds of negotiations themselves often take many years to complete. The second is that there have been so many rounds, or steps, in the liberalization process stretching out over so many decades. Neither of these features could be explained well within the picture of international trade agreements emerging from Figure 3, which would suggest no reason that the liberalization from a high-tariff outcome such as $\hat{\tau}^{\mathrm{N}}$ to the most-cooperative outcome $\hat{\tau}^{\mathrm{c}}$ couldn't be achieved in one great leap and without delay.

Understanding the reasons for delays in the process of negotiation and for gradualism in

\footnotetext{
${ }^{47}$ Whether such third-party sanctions play an important role in actual multilateral dispute settlement procedures such as GATT's is less clear. Certainly the role for explicit third-party sanctions is not large, although Article XXIII provides for the possibility of effectively expelling a notoriously offending country from GATT (see Jackson, 1969, pp. 186-187) and more subtle forms of third-party pressure are evident in practice (see Maggi, 1994).
} 
the process of reciprocal liberalization is important for several reasons. First, such an understanding may help to illuminate the pros and cons of various paths to liberalization, such as regional versus multilateral initiatives, and the implications of each for the other. Second, understanding the success of post-war liberalization may require an understanding of the process by which that success was achieved. The GATT process of on-going rounds of liberalization has been credited with generating the momentum for this success, and has lead to an informal "bicycle" theory of GATT: Unless you keep pedaling, you will fall off (Bhagwati, 1988, p. 41). And third, by understanding the reasons for delays in the negotiation process and the gradual nature of trade liberalization, changes in the institutional structure may suggest themselves that would help to reduce delays and hasten liberalization where desirable.

Of related but independent interest is the role that MFN has played in the process of multilateral trade negotiations. Asymmetries across countries are likely to lead to different bargaining outcomes in the presence of MFN as compared to the outcomes that would arise in its absence, both in terms of efficiency properties and in terms of distributional consequences. An important question is whether these differences are desirable.

In this section I will discuss a literature that relates to these issues. I will begin with the literature on trade bargaining under MFN. Next I will discuss delays in trade negotiations, and then consider gradualism in the liberalization process itself. After that, I will turn to the bicycle theory, and discuss the importance of the process by which liberalization has proceeded for the success that has been achieved. Finally, I will conclude this section by considering how regional liberalization initiatives which are able to out pace the multilateral liberalization process may affect the degree of multilateral liberalization attainable.

\subsection{Trade Bargaining and MFN}

Abiding by the principle of MFN is a central obligation under GATT, but the economic case for such a principle is far from clear. ${ }^{48}$ Against the potential benefits of MFN that come from avoiding the transactions costs and "trade diverting" effects associated with the ability to

\footnotetext{
${ }^{48}$ The MFN clause in trade agreements has a long and interesting history which pre-dates GATT. See Jackson (1969, pp. 249-255) on the history of MFN leading up to its inclusion in GATT. Also, while a distinction can be made between conditional and unconditional MFN (the former requiring the granting of some reciprocal privilege as a condition for MFN treatment), I will focus throughout on unconditional MFN as has the literature which I review.
} 
offer preferential treatment to selected trading partners are the potential costs associated with "free riding" on the reciprocal agreements of others (Viner, 1924, 1931, 1936). The free-rider issue has been explored with formal bargaining models in several recent papers.

Caplin and Krishna (1988) formally illustrate the free-rider problem associated with MFN in a static model of simultaneous bilateral bargains. MFN's requirement that each country in a bilateral bargain lower its tariffs to other countries not involved in the bargain creates an externality which is not internalized in the bilateral bargaining process. Consequently, a simultaneous round of bilateral bargains under MFN may be less effective at lowering tariffs than would be the case if MFN treatment were not required. Caplin and Krishna also explore the role of MFN in a three-country dynamic (sequential) bargaining context based on Rubinstein (1982), in which one country makes tariff-cutting proposals alternately to the second and third countries until an agreement is reached (which in equilibrium occurs immediately). Their results suggest that MFN may have important effects on the distribution of bargaining power across countries.

This theme is picked up by Ludema (1991), who constructs a three-country, noncooperative, dynamic bargaining game in which the choice between bilateral and multilateral tariff reductions is endogenous. In Ludema's model, when one country makes a proposal to the other two, they respond simultaneously to the proposal with acceptance or rejection. If both countries accept, agreement is reached and the negotiations end. If both reject, negotiations continue with the next proposer selected at random. But if one country accepts and the other rejects. the initial acceptance is taken to be on an ad referendum basis, and the accepting country is allowed to reconsider its position given that the third country has rejected. Ludema establishes that bargaining in this setting under MFN will yield tariff agreements which are Pareto efficient on the set of MFN tariffs, and in this sense the free-rider problem often associated with MFN does not arise. Intuitively, Ludema shows that any rational proposal made by one country must leave the other two countries indifferent between accepting the proposal and rejecting it and continuing negotiations. If, faced with such a proposal, one of the two remaining countries attempted to "free ride" on the MFN tariff concessions of the others by rejecting the proposal in the hope that its acceptance by the other country would lead to a bilateral agreement between that country and the proposer, the remaining country would then choose to reject (since it was just indifferent between rejection and acceptance of the full multilateral agreement at the ad 
referendum stage) and negotiations would continue. As a consequence, the MFN externality provides no advantage for free-riders in this setting. This does not mean that MFN has no efficiency costs, since the negotiated tariff equilibrium under MFN may not be Pareto efficient on the wider set of tariffs that include discriminatory tariffs. But it does suggest that the efficiency costs of MFN may be smaller than is commonly perceived. ${ }^{49}$ On the other hand, like Caplin and Krishna (1988), Ludema does associate distributional effects with MFN, in that he finds that all countries gain from negotiations under MFN but not necessarily in its absence.

All in all, by formalizing and evaluating the free-rider issues associated with MFN, this literature has raised doubts about the importance of these effects, suggesting that the efficiency cost of MFN may not be large. On the other hand, the benefits of MFN have not yet been adequately captured in a formal model, and so a convincing rationale for MFN is still lacking. As Caplin and Krishna observe:

There is a simple observation which illustrates the difficulties in providing a general bargaining-theoretic rationale for MFN. There is a grand utility possibility frontier available to countries using all the commercial trading instruments at their disposal, such as tariffs. If we view the bargaining process as yielding efficient outcomes, as for example with the Nash bargaining solution, then MFN simply limits the tools available to different countries, shifting in the utility possibility frontier. Hence the most positive aspects of MFN can only be illustrated when the bargaining process absent-MFN yields inefficient outcomes. (Caplin and Krishna, 1988, pp. 281-282).

This seems to point in a fruitful direction for future work in this important area.

\subsection{Negotiation Delay}

I will consider next the literature on negotiation delay. While there is a large literature focused on delays in negotiations generally (see, for example, a recent review of this literature by Kennan and Wilson, 1993), the literature explaining delays in the process of trade negotiation is still in its infancy. ${ }^{50}$ Bac and Raff (1994) appear to be the first to consider formally the role of bilateral incomplete information in generating delays in the completion of trade talks. Each country's private information concerns whether it is a "tough" type (refusing to make any tariff concessions of its own, but benefiting from any tariff concessions made by its trading partner) or a "soft" type (willing to make unilateral tariff concessions but also benefiting from any tariff

\footnotetext{
${ }^{49}$ A similar point is made by Maggi (1994), who argues that the efficiency costs of imposing MFN in a multilateral bargaining context may be small.

so Agreements are reached immediately in Caplin and Krishna (1988) and Ludema (1991). Matsuyama (1990) considers reasons for delay in trade liberalization, but my focus here is on delay in negotiation.
} 
concessions made by its trading partner). Countries enter into negotiations aware that any outcome of the negotiations must be self-enforcing in an infinitely repeated tariff game with subgame perfect punishments. It may benefit a soft-type country to attempt to masquerade during the negotiations as a tough type by "holding out," in the hope of extracting unilateral concessions from the other country. Bac and Raf show that soft-type countries may adopt these delaying tactics in a mixed strategy equilibrium, and that drawn-out negotiations may be necessary to complete the process of Bayesian updating that must ultimately lead one side to concede and an agreement to be reached. Thus, as in the larger literature on bargaining delays, drawn out trade negotiations may generate an unavoidable cost of private information as a result of the learning that must occur before agreement can be reached.

Whether there is more to be said in the context of delays in international trade negotiations than has already been said in the general bargaining literature is not clear. To generate further insights, it may well be necessary for researchers to introduce detailed institutional structure in order to capture what is unique in this problem to trade negotiations. ${ }^{51}$

\subsection{Gradualism}

I now turn to the literature concerned with gradualism of the reciprocal trade liberalization process itself. By this I mean the literature that seeks to explain why reciprocal trade liberalization seems to proceed in a long series of steps. While the general issue of gradualism in the reform process is a topic that has received a great deal of attention as a result of the many recent attempts at unilateral macroeconomic and structural reform, it is an issue of special significance in the case of reciprocal trade liberalization, where at the multilateral level reciprocal reform has been proceeding with the same basic goal for 50 years. ${ }^{52}$ It is hard to think of an example of a coherent unilateral economic reform program, trade or otherwise, that has exhibited gradualism to this extreme.

\footnotetext{
' Nevertheless, there are other insights from the bargaining literature that seem to have special significance in international trade applications. One example would be the relevance for the issue of multilateral versus bilateral approaches to trade liberalization of the findings of Mailath and Postlewaite (1990) that the length of delay in bargaining increases with the number of privately informed parties to the negotiation.

$\$ 2$ Other long episodes of reciprocal trade liberalization in the context of regional agreements are noted in Dam (1970, pp. 282-283).
} 
Nevertheless, a good place to begin is with the literature on gradualism in unilateral trade reforms, since the optimal pace of unilateral trade liberalization is likely to affect the pace of reciprocal trade liberalization as well. Mussa (1984) argues that adjustment costs by themselves are not a reason for gradualism in the reform process. That is, workers or other factors of production who face adjustment costs may choose to make their sectoral reallocation decisions slowly over time, but that does not imply that the reform itself should proceed slowly. Mussa shows that the optimal reform will be instantaneous in the presence of adjustment costs unless other market distortions are present, or unless the government chooses gradual reform to minimize its distributional consequences. Dewatripont and Roland (1992) and Brainard and Verdier (1994) study cases of unilateral trade liberalization in the presence of specific market imperfections, and provide reasons to expect that such reforms may proceed gradually. Dewatripont and Roland show how dynamic adverse selection can lead to gradualism in the reform process when a government lacks the ability to commit with regard to its private sector not to use information revealed in a partial reform for the design of later reforms. Brainard and Verdier examine the implications for the speed of unilateral trade liberalization of introducing political economy concerns into a model of quadratic (labor) adjustment costs.

As noted, the considerations that determine the optimal pace of unilateral trade liberalization are likely to affect the pace of reciprocal trade liberalization as well. But when trade liberalization requires reciprocal agreement between or among governments, there are likely to be additional reasons for gradualism. Two papers that focus on gradualism in reciprocal trade liberalization point to strategic interaction across governments as a potentially important additional explanation. These are the papers by Devereux (1993) and Staiger (forthcoming). Both papers focus on non-stationarities in the government incentive constraints that are triggered by initial liberalization, and lead to the possibility of further incentive compatible liberalization at some point in the future.

Devereux explores the relationship between trade liberalization and economic growth in a setting where production technologies exhibit learning-by-doing and governments set tariffs in an infinitely repeated game. Although his focus is on the relationship between trade liberalization and growth, the model he develops exhibits gradualism in the trade liberalization process. That is, the government incentive constraints that define the most-cooperative tariffs in every period 
are gradually relaxed over time by the effects of learning-by-doing in the model, provided only that the initial liberalization starts the process off by moving resources into each economy's export sector. Essentially, as the learning-by-doing in each economy's export sector out-paces the rate of (domestic) technological advance in its import-competing sector, the two economies become increasingly dependent on one another, and (i) the payoff from unilateral defection declines ( $\Omega\left(\tau^{\mathrm{c}}\right)$ is now time-dependent and shifts downward over time in Figure 3) and (ii) the gains associated with avoiding a trade war rise $\left(\omega\left(\tau^{c}\right)\right.$ is now time-dependent and increases over time, so that $\mathrm{V}\left(\delta, \tau^{c}\right)$ shifts up over time in Figure 3). This allows the most-cooperative tariff $\hat{\tau}^{c}$ to fall over time as learning proceeds.

A gradual process of trade liberalization can also arise if two changes are introduced to the model underlying Figure 3 (the following builds on Staiger, forthcoming). First, allow rentearning workers in the import-competing sector with sector-specific skills to relocate in response to changing tariff levels. Second, allow the sector-specific skills of workers who have exited the import-competing sector to depreciate over time. The key point to observe is that the presence of resources in an import-competing sector that are (or could be) earning rents from their sectorspecific skills will exacerbate the government incentive constraints associated with low cooperative tariffs and limit the degree of attainable trade liberalization. Intuitively, by being able to transform into rents a portion of what otherwise would be dead-weight loss under a tariff hike, the presence of such resources makes deviation from a low cooperative tariff to a high tariff more desirable for the deviating country, and makes punishments under reciprocally high tariffs less painful. But this in turn suggests that liberalization, which leads to the relocation of some of the existing import-competing workers, might eventually feed back upon itself and pave the way for further liberalization, if the workers who leave the import-competing sector eventually see that portion of their skills which is specific to the import-competing sector -- and hence their ability to earn rents in the sector should the government return to a higher tariff -- depreciate over time through lack of use.

The basic point can be illustrated with reference to Figure 3. If import-competing resources employed outside the import-competing sector face some probability each period of seeing their sector-specific skills deteriorate, then the amount of resources left in the economy with the potential to collect rents in the import-competing sector will eventually be diminished 
by the previous round's liberalization and the exit from the import-competing sector that it causes. As a consequence, the one-time payoff associated with defection from the low cooperative tariff $\tau^{c}$, which falls as the potential for rent collection associated with defection falls, will be given by the function $\Omega\left(\tau^{\mathrm{c}}, \hat{\tau}^{\mathrm{c}}{ }_{-1}\right)$. This function is decreasing in $\tau^{\mathrm{c}}$ over the relevant range as in Figure 3 but increasing in $\hat{\tau}_{-1}^{c}$, the equilibrium most-cooperative tariff achieved in the previous round. Similarly, the one period stake in maintaining cooperation at $\tau^{c}$ will be given by the function $\omega\left(\tau^{c}, \hat{\tau}^{c}{ }_{-1}\right)$, which is decreasing in both $\tau^{c}$ and $\hat{\tau}^{c}{ }_{-1}$. Thus, the discounted value of maintaining a cooperative trading relationship into the infinite future, suppressing (in notation only) dependence on the future path of equilibrium cooperative tariffs, will be given by the function $\mathrm{V}\left(\delta, \tau^{\mathrm{c}}, \hat{\tau}^{\mathrm{c}}{ }_{-1}\right)$ which is decreasing in both $\tau^{\mathrm{c}}$ and $\hat{\tau}^{\mathrm{c}}{ }_{-1} .^{53}$ Hence, as a round is completed and the resulting tariff cuts yield a cooperative tariff $\hat{\tau}^{c}$ that causes current incentive constraints to bind $\left(\Omega\left(\hat{\tau}^{c}, \hat{\tau}^{c}{ }_{-1}\right)=V\left(\delta, \hat{\tau}^{c}, \hat{\tau}^{c}{ }_{-1}\right)\right)$, a process is set in motion which will eventually cause $\Omega\left(\tau^{c}, \hat{\tau}^{c}{ }_{-1}\right)$ to shift down and $V\left(\delta, \tau^{c}, \hat{\tau}^{c}{ }_{.1}\right)$ to shift up, permitting a further round of liberalization to go forward at some point in the future.

If the discount factor is sufficiently high that free trade (or, in terms of Figure $3, \tilde{\tau}$ ) can be achieved in a finite number of rounds, then the entire most-cooperative path of liberalization can be solved recursively, by checking that the incentive constraint is met with equality for each round of liberalization leading up to the round that will ultimately pave the way for free trade. The features of the liberalization process in this model can be described simply. An initial round of liberalization induces a portion of the import-competing workers to leave the sector and put their import-competing skills at risk of depreciating. Once their skills depreciate, and these workers lose their ability to seek rents in the import-competing sector in the event of a return to high tariffs, the enforcement issues associated with sustaining the previous round's achievements are mitigated, making possible the next round of liberalization, which results in further tariff reductions. This round of liberalization induces a portion of the remaining import-competing workers to leave the sector, placing their import-competing skills at risk of depreciating, and the

${ }^{53}$ The function $V\left(\delta, \tau^{c}, \hat{\tau}^{c}{ }_{11}\right)$ will be decreasing in $\tau^{c}$ for two reasons. First, $V\left(\delta, \tau^{c}, \hat{\tau}^{c}{ }_{.1}\right)$ will be decreasing in $\tau^{\circ}$ for the same reason that $V\left(\delta, \tau^{\circ}\right)$ was in the original stationary model underlying Figure 3 . And second, the equilibrium path of future tariffs will be higher if $\tau^{\circ}$ is higher, and this indirect effect will also make $V\left(\delta, \tau^{c}, \hat{\tau}^{c}{ }_{-1}\right)$ decreasing in $\tau^{\circ}$. 
process of liberalization continues.

\subsection{The Bicycle Theory}

That the process of liberalization can gather momentum and sew the seeds of further liberalization is encouraging for the prospects of reciprocal trade liberalization, but there is also a more ominous side: Anything that interrupts the expected future progress of the liberalization process may impact negatively on the ability to sustain the liberalization that has already been achieved. This notion embodies the core feature of what has become informally known as the "bicycle" theory of GATT. It emerges naturally when reciprocal liberalization is viewed from the perspective of a self-enforcing agreement. This point can be seen with reference to the augmented version of Figure 3 just discussed, by observing that the position of $V\left(\delta, \tau^{c}, \hat{\tau}_{-1}^{c}\right)$ incorporates the entire anticipated equilibrium path of tariff liberalization. If an unanticipated event were to postpone or disrupt the expected path of future liberalization, then the discounted value of maintaining the integrity of the agreement into the future would have to be recalculated with this less favorable liberalization path taken into account. This implies that $\mathrm{V}\left(\delta, \tau^{c}{ }^{\mathrm{c}} \hat{\tau}_{-1}^{\mathrm{c}}\right)$ would shift down in Figure 3, and the current tariff level $\hat{\tau}^{c}$ achieved in the last round of liberalization could no longer be sustained (see Staiger, forthcoming, for an elaboration on this point). Hence, according to this view, past GATT successes become hostage to the continuation of the process which made those successes possible.

\subsection{Regionalism and its Implications for Multilateral Liberalization}

In light of the delay and gradualism reflected in historical experience with general multilateral liberalization, it is natural that smaller groups of countries may find it both feasible and in their mutual interest to proceed with liberalization at a faster pace than the multilateral trading system at large. This requires a fundamental exception to the principle of MFN, and the conditions under which such an exception will be granted for purposes of forming a regional trade arrangement are spelled out in Article XXIV of GATT. The Chapter by Richard Baldwin and Tony Venables in this Handbook treats the many dimensions of regional integration in detail. Here I focus narrowly on one question: What are the implications of regional trade agreements for the operation of multilateral trade agreements?

From a historical perspective, it appears that the formation of regional trade agreements can provide an impetus to further liberalization at the multilateral level, at least judging from 
GATT's response to the formation and later broadening of the European Community: The future prospect of an integrated European Community market devoid of internal barriers but with common external tariffs was seen as a major factor leading to the Kennedy and Tokyo Rounds of GATT negotiations (see, for example, Bergsten, 1991). However, the impact of regional agreements on liberalization at the multilateral level has recently received renewed interest as countries have begun to turn with increasing frequency to regional trade agreements. The continued integration of the European Community culminating in EC92, and the integration of North America beginning with the U.S.-Canada Free Trade Agreement and continuing with the addition of Mexico under the North American Free Trade Agreement, are but the most prominent examples of regional trade liberalization that have occurred over the past decade. In contrast with the earlier episodes of regional integration, associated with these recent efforts to liberalize at the regional level has been a growing concern that continued efforts to liberalize at the multilateral level could be undermined as a consequence.

There are several ways to evaluate the basis for this concern. One possibility might be to ask how the internal political support for multilateral trade liberalization would be affected by regional integration. A second might be to ask how regional integration might affect the bargaining outcomes of multilateral trade negotiations. A third might be to consider the impact of regional integration on enforcement issues at the multilateral level. A complete answer might attempt to address all of these questions together, since they are unlikely to be independent. However, useful insights can be obtained by examining each of these questions in isolation, which is what the literature to date has done.

Levy (1994) considers the first question, that is, whether opportunities to negotiate bilateral trade agreements might undermine political support for broader multilateral liberalization. He establishes, in a median-voter model, that such an "undermining" result is, in fact, not possible if trade occurs in a standard $2 \times 2 \times 2$ Heckscher-Ohlin setting. However, in the presence of trade based in part on increasing returns and product variety, bilateral agreements between sufficiently similar countries can undermine political support for multilateral liberalization. The intuition for this result can be seen by considering the political implications of a bilateral agreement between two identically endowed countries when, absent such an agreement, political support in these two countries for multilateral liberalization would be 
"marginal," i.e., the median voters would be just slightly better off under multilateral free trade than under the status quo trading arrangements. If, in the absence of such a bilateral free trade area, the median voters in each of the two countries would only marginally prefer multilateral liberalization to the status quo, then their marginal support must reflect the near balance of two effects of multilateral liberalization on the welfare of the median voter. These are the redistributive Stolper-Samuelson effects and scale-economy/variety effects. Since the scaleeconomy/variety effects of multilateral liberalization are generally beneficial to all voters, including the median voter, the redistributive effects of the relative price changes that would come about from multilateral liberalization must work against the median voters in the two countries if they are in fact just marginally supportive of the move to multilateral free trade. But then a bilateral agreement between these two identically-endowed countries would allow them to achieve a portion of the "politically easy" scale-economy/variety gains without having to suffer any of the "politically difficult" redistributive effects that come from relative price movements triggered by broader multilateral liberalization in a dissimilar world. Such a bilateral agreement would surely improve the welfare of each country's median voter over the status quo, but would also tip the scales against political support in these two countries for further multilateral liberalization, since the median voters in each country would no longer care to suffer the redistributive effects of multilateral trade liberalization in order to enjoy the remaining scale effects. Levy shows that this "undermining" is most likely to occur when the countries combining into regional trading areas are quite similar.

The impact of regional agreements on multilateral trade negotiations has been studied by Ludema (1993) in a three-country, dynamic, non-cooperative bargaining model. Neutralizing any efficiency effects of regional agreements by maintaining the assumption of costless international transfers, Ludema shows that the distribution of the gains from trade can be influenced by regional agreements. ${ }^{54}$ Ludema also draws a distinction between the bargaining advantages associated with the formation of a free trade area (whose member countries drop internal barriers to trade but maintain independent external trade policies) and those associated with a customs

\footnotetext{
${ }^{54}$ Maggi (1994) establishes the possibility of efficiency gains from multilateral trade bargaining over what could be achieved with a web of bilateral trade bargains in the absence of costless international transfers.
} 
union (whose members also agree to adopt a common external trade policy). In effect, the formation of a customs union provides a bargaining advantage to its member countries as a result of the strategic commitment afforded by its common external trade policy. Free trade agreements, on the other hand, need not actually be formed to have an impact on bargaining outcomes: The proposer can make credible threats to sign bilateral agreements in the event that its multilateral offer is rejected.

Finally, I turn to the impact of regional integration on the enforceability of multilateral agreements. This issue has been addressed in the context of free trade agreements by Bagwell and Staiger (1993a), and in the context of customs unions by Bagwell and Staiger (1993b) and Bond and Syropoulos (1993). To interpret the findings of these papers, it is helpful to identify two principal effects of regional agreements: A trade diversion effect, whereby intra-member trade volume rises at the expense of trade between member and non-member countries; and a market power effect, which occurs if the member countries adopt a common external tariff policy (i.e., form a customs union) and enables them to impose higher (credible) tariffs on their multilateral trading partners should such punitive tariff action be desired.

Bond and Syropoulos (1993) compare the level of self-enforcing tariffs sustainable in an infinitely repeated tariff game when there are different (stationary) patterns of customs union formation. Their central finding is that the effectiveness of multilateral trade agreements is likely to suffer as a result of the (symmetric) formation of customs unions, i.e., the most-cooperative multilateral tariff $\hat{\tau}^{c}$ must rise with the formation of customs unions. In essence, they argue that both the one-time payoff from defection and the discounted value of maintaining future cooperation $\left(\Omega\left(\tau^{c}\right)\right.$ and $V\left(\delta, \tau^{c}\right)$, respectively, in Figure 3) will rise with the formation of customs unions owing to the market power effect; they find, however, in simulations of their model that $\Omega\left(\tau^{c}\right)$ rises proportionately more than $V\left(\delta, \tau^{c}\right) .^{55}$

Bagwell and Staiger (1993a, 1993b) adopt a somewhat different focus. They view the period of transition, during which a regional agreement is negotiated and then implemented, as a crucial feature of the formation of regional trade arrangements, and explore how the process

ss They also consider the effects of size asymmetries on tariff liberalization, and find that, in a two bloc world, liberalization is more difficult the greater the difference in bloc size. 
of regional bloc formation can alter the prior balance of incentives that supported the mostcooperative multilateral tariff level $\hat{\tau}^{c}$. Consider first the formation of a free trade agreement, which entails trade diversion away from multilateral trading partners at the end of the transition period. As the transition begins, the current temptation to cheat on the wider multilateral agreement remains basically as before $\left(\Omega\left(\tau^{c}\right)\right.$ in Figure 3 remains in place), since multilateral trade patterns are at this point still the same. But the cost of a future trade war triggered by cheating on the multilateral agreement now seems less ominous $\left(V\left(\delta, \tau^{c}\right)\right.$ shifts down in Figure 3) owing to the expected future trade diversion and reduced reliance on multilateral trading partners. Hence, as the transition associated with the formation of free trade agreements begins, the effectiveness of the multilateral trade agreement will deteriorate ( $\hat{\tau}^{c}$ rises in Figure 3 ). By the end of the transition, however, the expected trade diversion will have occurred $\left(\Omega\left(\tau^{\tau}\right)\right.$ will fall in Figure 3), and the imbalance between current and expected future multilateral trading relationships that arose during the transition will once again subside, allowing multilateral trade barriers to return to more normal levels as well ( $\hat{\tau}^{c}$ falls back down in Figure 3 ). Thus, the effectiveness of multilateral trade agreements worsens during the transition period to a fully implemented free trade agreement, but improves again once the transition period is over.

In an analogous way, the market power effect of customs union formation leads to the opposite prediction for the performance of multilateral trade agreements as this kind of regional bloc is formed: Prospects for multilateral tariff liberalization improve during the transition period to a fully implemented customs union, but worsen again once the transition period is over. Intuitively, as the transition period begins, non-member countries are less apt to take a confrontational stance in trade disputes with member countries of the emerging customs union, as the risks of a possible trade war with such countries now pose a greater deterrent to confrontation than they once did. Eventually, however, as the impact of the emerging customs unions on the degree of market power becomes felt, the "honeymoon" period for multilateral liberalization ends. and a less favorable balance between current and expected future conditions reemerges.

\section{Safeguards and Managed Trade}

If the extended decline in multilateral tariff levels represents one major feature of post-war trade policy, the move toward "special" protection which has accompanied it represents a second. 
As noted in Section 2, the possibility of temporary reversions to high protection or on occasion even permanent reversal of previous tariff reductions was anticipated to be a part of the natural process of liberalization, and was viewed as an inevitable consequence of low levels of baseline protection envisioned by GATT. But while the safeguards included in GATT were meant to keep the inevitable deviations from rigid tariff bindings within GATT rules, in practice the growing use of VERs, VIEs, OMAs, and tariff programs that are tailor made to suit the needs of particular sectors signal a failure of the rules to contain these actions, and have given rise to the term "managed trade."

There are several dimensions on which the so-called "grey-area" measures that form the tools of managed trade might be said to have spilled over the confines placed on them by GATT rules. A first dimension is simply the frequency and intensity with which they have been used. Recent estimates by Trefler (1993), for example, suggest that the non-tariff barriers in place for the United States manufacturing sector in 1983 reduced U.S. manufacturing imports by $24 \%$, calling into question the "special" nature of the protection that takes this form. A second dimension is the duration of many of these grey-area measures. While for the most part safeguard actions are viewed as temporary measures within GATT, a number of instances of extended protection, e.g., textiles and the Multi-Fiber Arrangement, have clearly surpassed any reasonable definition of temporary. A third dimension is the form that these measures have taken, often providing for the "target" country to share in administration and rent-collecting actions associated with the measure. ${ }^{56}$ In this section I will discuss a number of papers which bear on each of these dimensions.

\subsection{Frequency and Intensity}

What does it mean for countries to utilize the tools of special protection "too" frequently and aggressively? Two possible interpretations are suggested by the literature, and both can ultimately be traced to weak enforcement mechanisms. These interpretations correspond to the two environments described in Section 3 where adherence to international rules could be beneficial, and in each case weak enforcement of the rules limits their potential usefulness.

\footnotetext{
${ }^{56}$ There is also the fact that these measures are often quantitative in nature, and therefore go against GATTs emphasis on "tariffication." See note 12 for a discussion of some of the literature relevant to this issue.
} 
Where the central strategic interaction is across governments, Bagwell and Staiger (1990) have built on the work of Rotemberg and Saloner (1986) to show that weak international enforcement mechanisms will lead to episodes of special protection when trade volumes surge, as a way to cope with the temporary incentive problems that accompany such trade swings. More specifically, a period of high trade volume will tend to be associated with an especially high payoff in pursuing unilaterally preferred trade policies in that period. In terms of the incentives depicted in Figure 3, this will correspond to an upward shift in $\Omega\left(\tau^{c}\right)$. If this high trade volume is perceived as transitory, corresponding to a temporary "surge" with expected future trade volumes left unaltered, then the expected future cost of a trade war will be unaltered $\left(\left(\mathrm{V}\left(\delta, \tau^{c}\right)\right.\right.$ will not shift in Figure 3$)$. Where the desire to avoid a trade war is sufficiently strong so that enforcement was not an issue prior to the surge $\left(\left(\mathrm{V}\left(\delta, \tau^{\mathrm{c}}\right)\right.\right.$ is greater than $\Omega\left(\tau^{\mathrm{c}}\right)$ at $\left.\tilde{\tau}\right)$, no tariff response may be needed. However, if enforcement is sufficiently weak $\left(\left(\mathrm{V}\left(\delta, \tau^{c}\right)\right.\right.$ is sufficiently low in Figure 3), the tariff binding that was supportable prior to the surge in trade volume can no longer be sustained. This does not imply that the international trade agreement need break down. Instead, countries can agree to use special protection during periods of exceptionally high trade volume to mitigate the unilateral incentives to defect. ${ }^{57}$ The frequency and intensity of use of special protection according to this view is then determined as the minimum required to maintain the incentive compatibility of the overall agreement in the presence of volatile trade swings. Generally, the weaker the enforcement mechanism, the greater the dependence on special protection necessary to maintain the integrity of the agreement. ${ }^{58}$

A second interpretation of the too-frequent use of special protection is associated with the literature on time-consistent trade policy and the possible role of international rules in providing governments with greater credibility in their use of trade policies in responding to injured sectors. Where these rules are weak and domestic institutions inadequate to provide the needed commitment, special protection is likely to be over-utilized relative to a government's optimal but time-inconsistent plan (see, for example, Staiger and Tabellini, 1987, Matsuyama,

\footnotetext{
${ }^{57}$ For some empirical evidence relating to this interpretation, see Dick (1994).

s8 Maggi's (1994) findings on the role of multilateral enforcement mechanisms in the presence of local imbalances of power (e.g., bilateral trade imbalances) also suggests an interpretation of VIEs as a mechanism for reducing local imbalances of power when multilateral enforcement mechanisms are weak.
} 
1990, Brainard, 1994, and Mayer, 1994). But while these papers all suggest that GATT rules could be helpful as a commitment device when confronting injured sectors, it is in precisely these situations that GATT commitments can be suspended under the safeguards provisions of the agreement. ${ }^{59}$ There would appear to be a tradeoff between flexibility and rigidity in such circumstances that, as indicated above, may be an important element of the design of international trade agreements when enforcement mechanisms are weak, but may also serve to undercut or at least severely limit the effectiveness of international agreements in providing the kind of commitment benefits suggested by the literature. ${ }^{60}$ If this is the case, then GATT rules may provide little in the way of commitment when countries face import surges, and overutilization of special protection may be the rule rather than the exception.

\subsection{Duration}

Matsuyama (1990) is concerned with the credibility of temporary protection in a situation where the government would find it optimal to offer such protection if the "temporary breathing space" were used by the protected industry to make adjustments that prepared it to face import competition without the benefit of protection in the future. One interpretation of the reducedform payoffs in his model is that the government has distributional concerns and would be willing to offer temporary protection to an injured sector if such protection allowed adjustment to import competition to occur in a way that reduced the resulting distributional consequences, e.g., minimized sectoral unemployment.

The structure of the game played between a government and an import-competing industry in Matsuyama is as follows: In the first period, the government chooses whether or not to liberalize the (pre-existing) tariff. If it chooses to liberalize, the game ends. But if it chooses to protect for the period, then the industry chooses whether to "prepare" for liberalization next period or not. This structure repeats itself in all subsequent periods until the game ends; i.e., until the government chooses to liberalize. The general credibility issue arising here is in regard

\footnotetext{
${ }^{59}$ Empirical evidence that GATT rules do serve this function more generally, and that escape clause actions do not benefit from this disciplining role, is presented in Staiger and Tabellini (forthcoming), though Rodrik (1993) provides some evidence to the contrary.

${ }^{60}$ The literature on strategic delegation (see, for example, Katz, 1991) may suggest promising avenues for research in this area.
} 
to the temporary nature of the protection afforded. If the government finds that it is in its interest to offer "temporary" protection today so that the industry can use today to prepare for trade liberalization tomorrow, and if tomorrow comes and the industry has not chosen to prepare, what ensures that the government will not renew the "temporary" protection tomorrow, especially since it will then find itself tomorrow in exactly the same position as today? And if the industry can be sure that "temporary" protection will be renewed tomorrow if it chooses not to prepare today, then it will never choose to prepare, and the government's "temporary" protection program cannot be temporary.

Matsuyama examines the set of Nash outcomes to this game under a number of equilibrium refinements that imply successively more stringent "credibility" criteria. He finds that the optimal one-period protection plan -- give the industry one period to prepare and then liberalize -- will not be renegotiation-proof in either the sense of Farrell and Maskin (1989) or Pearce (1987). The interpretation of the possible effects of rules in this context would be that, through adherence to them, a government might be able to relax some of the equilibrium refinements that rule out the optimal protective policy as an equilibrium outcome. However, if international enforcement mechanisms are weak, so too would be the effect of international rules on reducing the length of "temporary" protection.

\subsection{Form}

Managed trade is often characterized by a distinctive form of intervention. Frequently, the protective measures are negotiated, and often the agreement calls for sharing of administration and rent-collecting functions by the countries involved. Several papers have addressed the question of what role such forms of protection, as opposed to a more standard unilaterallyimposed tariff, could play in facilitating or hindering the operation of broader international trade agreements. While institutional efforts have been made to reign in these forms of special protection (the safeguards provisions of the Uruguay Round GATT agreement explicitly proscribe the former grey area measures) the literature suggests reasons for at least some caution in determining how far to go this regard, in that eliminating completely the ability of countries to use these forms of protection might actually interfere with the operation of the broader trade agreements to which they are a perceived threat.

Feenstra and Lewis (1991) explore whether the rent-sharing aspects of managed trade 
might serve some role in facilitating trade agreements between countries facing private political pressure. In a setting where countries must negotiate a long-term trade agreement that specifies a trade policy "safeguard" action under all future contingencies of political pressure, and where that political pressure will be privately observed, Feenstra and Lewis derive the optimal incentivecompatible trade policies. They interpret the form of the optimal policy to be a tariff-quota. The rent-sharing aspect of such negotiated protection serves the role of maintaining incentive compatibility of the agreement, as a government will then have incentive to announce truthfully its privately observed political pressure. That is, the truthful reporting of political pressure is ensured by transferring some of the rents from special protection to foreigners. Bagwell and Staiger (1990), Ono (1991), and Eaton and Ono (1992) also find that the distribution of rents created by special protection will generally be an important factor in maintaining incentive compatibility of trade agreements, though the incentive compatibility issues analyzed by these authors arise in the context of enforcement rather than truth-telling.

\section{Antidumping Law and Countervailing Duties}

While antidumping and countervailing duty laws are typically referred to as "unfair trade" laws, the practices they are meant to address (dumping by foreign firms and subsidies by foreign governments, respectively) are not generally proscribed by GATT. ${ }^{61}$ As Jackson (1969) notes:

...The GATT approach was to leave these dumping and subsidy measures generally legal, but to arm importing nations with an exception to GATT obligations to enable them to defend against these practices by antidumping and countervailing duties. (Jackson, 1969, p. 403).

In the case of dumping, this approach evidently reflects the fact that such behavior is a phenomenon of private firms, not governments, and proscribing it is therefore beyond the scope of traditional government obligations under GATT (see Jackson, 1969, p. 402). In the case of subsidies, this approach reflects the view, as expressed in the preamble of the GATT Subsidies Code, that such policies can have a legitimate role to play in promoting national objectives. Therefore, the role of international trade agreements where subsidies are concerned is generally not to attempt to control their use directly, but simply to keep to a minimum their trade effects. Antidumping and countervailing duty provisions have as a result found their way into many trade

\footnotetext{
${ }^{61}$ There is no general proscription against dumping in GATT, while that against subsidies is limited to export subsidies on non-primary products for developed countries (see Jackson, 1969, p. 377, and Hufbauer and Erb, 1984, Ch. 2).
} 
agreements to counteract actions which are out of reach of direct disciplines.

Article VI of GATT lays out conditions under which antidumping and countervailing duty actions can be taken with the intent of preventing their misuse. Characterizing and understanding the potential for misusing these provisions, as well as the potential for unintended effects of the provisions even when they are used in the circumstances for which they were intended, has been the focus of a growing literature that I discuss briefly below. However, before turning to this literature, I briefly discuss the prior question of whether efforts to counteract the effects of foreign subsidies or foreign dumping make sense from an economic perspective. That is, while the intended role of GATT's Article VI and provisions like it in other trade agreements may be to keep in check the potential for misusing antidumping and countervailing duty actions, why should an international trade agreement allow these kinds of actions to be taken in the first place? ${ }^{62}$

\subsection{The Response to Dumping and Export Subsidies}

Because the antidumping and countervailing duty provisions of an international agreement such as GATT specify conditions under which exceptions can be made to certain obligations under the agreement, one approach to evaluating the place of these provisions in a broader trade agreement is to view them as additional "safeguards," similar to a general escape clause but available only under particular circumstances. ${ }^{63}$ From this perspective, two central questions arise: How do these provisions differ from those associated with general escape clause actions?; and to the extent that they do differ, do the circumstances under which these provisions are made available warrant special exceptions to obligations under an international trade agreement beyond what are available from a general escape clause?

As to the first question, there are several important differences between antidumping and

62 See Dixit (1988) for an interesting analysis of the role of antidumping and countervailing duties in a setting where foreign government policies are set exogenously, and Collie (1991) for an extension of Dixit's results on countervailing duties to a setting where foreign government policies are responsive to domestic policy choices. Gruenspecht (1988) observes that mutual antidumping enforcement across countries can lead to a Prisoner's Dilemma situation. However, none of these papers address the general role of antidumping and countervailing duty provisions in the context of international trade agreements.

${ }^{63}$ Prusa and Hansen (forthcoming) describe this view in their analysis of the industry-level choice between filing an antidumping or countervailing duty petition versus an escape clause petition. 
countervailing duty provisions and the escape clause found in GATT and other trade agreements. First and most obvious is the fact that antidumping and countervailing duty actions are not available to a country unless foreign firms are found to have dumped or foreign governments subsidized products for export. ${ }^{64}$ On the other hand, if such actions are found, the degree of injury to the domestic industry and the causal link from imports necessary to elicit antidumping or countervailing duty remedies is low as compared to the injury threshold for escape clause actions (see, for example, Jackson, 1989, pp. 149-165). Against this must be weighed the differences in actual remedies under each provision. While escape clause remedies are typically imposed against imports from all sources and are intended to be used only temporarily and to the extent necessary to remedy the injury, remedies under antidumping and countervailing duty law are intended to counter the amount of dumping or subsidization found, and thus apply to selected countries at levels and durations dictated by the foreign practices that the remedies are supposed to counteract. While the selective coverage of antidumping and countervailing duty actions diminishes their overall protective effect, the level and duration of the remedies involved combined with the low injury threshold required to secure these remedies evidently is sufficient to make them overwhelmingly the preferred "safeguard" action. This relative popularity is borne out in practice by the degree of utilization of each kind of remedy. Messerlin (1990) reports, for example, that of the 2,348 notifications to GATT of restrictions imposed between 1979 and 1988 , over 75 percent were antidumping actions and another 18 percent were countervailing duty actions, with safeguards actions accounting for only 3 percent of the total. It seems safe to conclude that the conditions for granting exceptions to international obligations are significantly more attractive when dumping or foreign subsidies can be asserted.

This leads to the second question raised above: Is there a basis for granting countries exceptions from their obligations under an international trade agreement more readily when dumping or foreign subsidies are involved? A satisfactory answer to this question requires attention to the underlying issues of why these foreign practices occur and what are their likely

\footnotetext{
${ }^{64}$ Recall that dumping is defined as exporting products at export prices "below fair value," i.e., either below the prices of comparable products for sale in the domestic market of the exporting country or below costs of production. The definition of a subsidy is a "bounty" or "grant" offered to producers, although coming to agreement on what constitutes a subsidy in practice is an issue fraught with difficulty (see, for example, Hufbauer and Erb, 1984).
} 
effects on other countries. Reviewing the literature on why firms dump or why governments subsidize their export sectors is beyond the scope of this chapter, and the specific question posed above has not been formally analyzed within the context of this literature. ${ }^{65}$ Thus, a formal answer must await further work. What can be said, however, is this: While a given fall in the price of foreign exports may well have the same impact on the domestic economy regardless of whether it is caused by a foreign government subsidy, a foreign firm that is dumping, or a change in the foreign firm's cost structure, this is not enough to conclude that the nature of the response to such a price shock within the broader context of an international trade agreement should be independent of the causes of that shock. Drawing this conclusion would ignore the strategic dimension of the problem, i.e., that the nature of the government response to foreign price changes may affect the nature of the foreign price changes themselves in a manner which depends on their underlying causes. ${ }^{66}$

\subsection{The Uses and Effects of Antidumping and Countervailing Duty Actions}

To the extent that antidumping and countervailing duty provisions do have a place in international trade agreements, the role of these provisions has been to place restrictions on the use of such actions. In this section I will discuss some of the literature that relates to the possible need for international constraints in this regard and the nature of the unintended effects and outright misuse of antidumping and countervailing duty actions that could occur in the absence of effective constraints. Three kinds of potential problems with the use of antidumping and countervailing duty law have been discussed in the economics literature: Measurement bias; unintended effects of "legitimate" use; and abuse. I will briefly discuss each in turn.

The measurement problems associated with administering these laws have received an

\footnotetext{
${ }^{65}$ Recent papers exploring the circumstances under which firms might engage in dumping include Ethier (1982), Brander and Krugman (1983), Pinto (1986), Gruenspecht (1988), Bagwell and Staiger (1989), Berck and Perloff (1990), Staiger and Wolak (1992), Weinstein (1992), Anderson (1992, 1993), and Clarida (1993). The voluminous literature on strategic trade policy (see the chapter by James Brander in this Handbook) and political economy (see the chapter by Dani Rodrik in this Handbook) is relevant for understanding why governments might subsidize their export sectors, as is the literature on informational barriers to entry (see, for example, Grossman and Horn, 1988, Bagwell and Staiger, 1989, and Bagwell, 1991).

${ }^{66}$ Certainly outside the context of a trade agreement such a conclusion would be false (see, for example, Collie, 1991, on the implications of strategic interactions across governments for the optimal countervailing duty response to a foreign government's export subsidy policy).
} 
enormous amount of attention (see, for example, the papers in Boltuck and Litan, 1991). This literature has focussed primarily on the way that dumping and subsidy margins have been calculated by the administrating authorities, and has detailed numerous difficulties with these procedures. A consistent finding is that there are strong biases in the methodologies adopted for dumping margin and subsidy calculations that predispose the authority to find a positive margin or subsidy. Many authors conclude that international rules regarding the acceptable procedures in calculating dumping and subsidy margins must be tightened if protectionist biases in the administering of these laws are to be avoided.

A number of papers have focussed on the unintended effects of enforcement of antidumping and countervailing duty laws that can arise even when the kinds of measurement issues pointed out above are absent and when the laws are being put to the purposes for which they seem to be designed. Gruenspecht (1988) explores the implications of mutual antidumping enforcement in a two-country two-period duopoly model in which dumping is defined as exporting at a price below marginal cost and the technology exhibits firm-specific learning-bydoing. The dynamic economies of scale can give rise to dumping in the first period, as firms attempt to capture a larger share of the second-period profits via lower second-period costs. Here, unilateral antidumping enforcement can serve as a rent-shifting devise, but mutual antidumping enforcement simply helps firms restrain their first-period output and raise first-period price, and in so doing raises second period prices and costs as well. A situation analogous to the Prisoner's Dilemma can result from mutual antidumping enforcement, with implications for the potential benefits of the restraining effects of international rules. Anderson (1993) makes a different point with regard to the unintended effects of antidumping law. Noting that the remedies available under antidumping law have in practice included "grey area" measures such as VERs, and that export licenses under a VER (which have rents associated with them) are often allocated on the basis of historical market shares, Anderson shows that stronger antidumping enforcement, by raising the probability of future VERs, can actually encourage dumping, as exporting firms are led to price more aggressively in order to secure a stake in the possibility of future VER-generated rents. Bagwell and Staiger (1989) reach a similar conclusion in a different context with regard to antidumping and countervailing duty law: In a setting where foreign firms view dumping as a way to break informational barriers to entry in an export market, domestic 
enforcement of antidumping and countervailing duty laws can encourage foreign export subsidies, as foreign firms refrain from dumping and foreign governments are induced to offer export subsidies instead (despite the countervailing duties imposed by importing countries) in order to break the informational barrier to entry. Finally, when a foreign monopolist dumps in order to reduce the cost of holding excess capacity in periods of slack demand, antidumping laws can restrict trade even when they are not being utilized, because the foreign monopolist will choose a smaller capacity in the presence of antidumping enforcement (see Staiger and Wolak, 1992).

I now come to the third kind of problem associated with these laws, namely that of abuse. Prusa (1992) has argued that antidumping petitions that are withdrawn by the domestic industry before a final determination, and that fail therefore to secure an antidumping duty, nevertheless may restrict post-investigation trade flows by as much as if antidumping duties had actually been imposed. Essentially, he argues that domestic firms can use the threat of antidumping duties, together with the protection from domestic antitrust laws afforded when an antidumping proceeding is in progress, to bargain with foreign firms over domestic market share, and that the antidumping petition is withdrawn by the domestic industry if and when an acceptable bargain is struck. ${ }^{67}$ Staiger and Wolak (1991) focus on the possible effects of antidumping law on trade flows and prices during the investigation process. They argue that domestic firms may make strategic use of an on-going antidumping investigation into the pricing and sales practices of their foreign competitors in order to prevent the occurrence of price wars that otherwise might be triggered by temporary downturns in demand and capacity utilization. Their results suggest that domestic firms may value the competition-dampening effects of an on-going antidumping investigation for its own sake, and may initiate such petitions when capacity utilization is low with no expectation that they would actually result in duties or other remedies. ${ }^{68}$

Taken together, these papers suggest some of the many ways that restrictions on the use of antidumping and countervailing duty law might be beneficial. But a more complete understanding of the appropriate role, if any, that these laws should play in the broader context of international trade agreements appears still to be needed.

\footnotetext{
${ }^{67}$ Prusa (1991) provides some empirical support for this view.

${ }^{68}$ Evidence of this is provided in Staiger and Wolak (1994).
} 


\section{Conclusion}

I conclude this chapter with four observations on possible directions for future research on trade rules and institutions. First, while there would appear to be many potentially fruitful ways to build on the research reviewed above, there are important dimensions of international trade agreements that seem to be almost completely unrepresented in the formal economics literature. Some of these areas have only recently become the subjects of serious trade discussions (for example, intellectual property rights, services, and investment). Others are noteworthy for their long omission from international trade agreements despite their obvious importance (for example, agriculture). Each of these areas presents distinct challenges for the design of international trade agreements, and formal economic analysis of the issues involved is needed. Moreover, the general topic of the sequence in which issues should be incorporated into international trade agreements seems an important and fruitful area to explore. Second, the important interaction between domestic and international rules and institutions as they relate to trade policy is a feature that needs to be introduced into the formal analysis reviewed above. Third, the degree to which governments can increase their credibility with the private sector by entering into international trade agreements that operate under the kinds of constraints discussed above is still an open question, and one that seems particularly important for improving our understanding of the benefits international trade agreements are capable of delivering. And finally, the different approaches to international rules and institutions for trade and for macroeconomic policy, both in their actual design (for example, contrast the approaches of the International Monetary Fund and World Bank with GATT) and in the academic literature concerned with them (contrast the literature reviewed here with that reviewed in the chapter by Torten Persson and Guido Tabellini in this Handbook and in Canzoneri and Henderson, 1991) suggests that each literature could learn from the other about the distinctive nature of the problems faced by policy-makers in these two arenas. 


\section{References}

Abreu, D., "Extremal Equilibria of Oligopolistic Supergames," Journal of Economic Theory 39, (1986).

Abreu, D., "On the Theory of Infinitely Repeated Games with Discounting, Econometrica 56, (March 1988)

Abreu, D., Milgrom, P. and D. Pearce, "Information and Timing in Repeated Partnerships," Econometrica 59, November 1991.

Anderson, J.E., "Domino Dumping I: Competitive Exporters," American Economic Review 82, (March 1992).

Anderson, J.E., "Domino Dumping II: Anti-dumping," Journal of International Economics, August 1993.

Bac, M., and H. Raff, "A Theory of Trade Concessions," mimeo, August 1994.

Bagwell, K., "Optimal Export Policy for a New-Product Monopoly," American Economic Review 81, (December 1991).

Bagwell, K., and R.W. Staiger, "The Role of Export Subsidies when Product Quality is Unknown," Journal of International Economics 27, 1989.

Bagwell, K., and R.W. Staiger, "A Theory of Managed Trade," American Economic Review, September 1990.

Bagwell, K., and R.W. Staiger, "Multilateral Tariff Cooperation During the Formation of Free Trade Areas," NBER Working Paper No. 4364, May 1993a.

Bagwell, K., and R.W. Staiger, "Multilateral Tariff Cooperation During the Formation of Customs Unions," NBER Working Paper No. 4543, November 1993b.

Baldwin, R.E., and R.N. Clarke, "Game-Modeling Multilateral Trade Negotiations," Journal of Policy Modeling 9, (Summer 1987).

Bayard, T.O., and K.A. Elliott, " 'Aggressive Unilateralism' and Section 301: Market Opening or Market Closing?" The World Economy, November 1992.

Berck, P., and J.M. Perloff, "Dynamic Dumping," International Journal of Industrial Organization, 8, 1990.

Bergsten, F.C., "Commentary: The Move Toward Free Trade Zones," in Policy Implications of Trade and Currency Zones, Federal Reserve Bank of Kansas City, Jackson Hole 
Wyoming: August 22-24, 1991.

Bergsten, F.C. and W.R. Cline, "Trade Policy in the 1980's: An Overview," in W.R.Cline (ed.) Trade Policy in the 1980's, Cambridge, MA: MIT Press, 1983.

Bernheim, B.D., and Whinston, M.D., "Multimarket Contact and Collusive Behavior," Rand Journal of Economics 21, Spring 1990.

Bhagwati, J., Protectionism, The MIT Press, Cambridge, Mass., 1988.

Bhagwati, J., The World Trading System at Risk, Princeton University Press, Princeton, New Jersey, 1991.

Bond E.W., and C. Syropoulos, "Trading Blocs and the Sustainability of Inter-Regional Cooperation," unpublished manuscript, March 1993.

Brainard, S.L., "Last One Out Wins: Trade Policy in an International Exit Game," International Economic Review 35, February 1994.

Brainard, S.L., and T. Verdier, "The Political Economy of Declining Industries: Senescent Industry Collapse Revisited," NBER Working Paper No. 4606, December 1993.

Brander, J.A., and B. Spencer, "Export Subsidies and Market Share Rivalry, Journal of International Economics, 18, 1985.

Brander, J.A., and P. Krugman, "A 'Reciprocal Dumping' Model of International Trade," Journal of International Economics 15, 1983.

Boltuck, R., and R.E. Litan, Down in the Dumps: Administration of the Unfair Trade Laws. Washington, D.C.:Brookings. 1991.

Canzoneri, M.B., and D.W. Henderson, "Monetary Policy in Interdependent Economies: A Game-Theoretic Approach. Cambridge, Mass.: The MIT Press. 1991.

Caplin, A., and K. Krishna, "Tariffs and the Most-Favored-Nation Clause: A Game Theoretic Approach," Seoul Journal of Economics 1, 1988.

Carmichael, C., "The Control of Export Credit Subsidies and its Welfare Consequences," Journal of International Economics, 23, 1987.

Clarida, R.H., "Entry, Dumping, and Shakeout," American Economic Review, 83, (March 1993).

Collie, D., "Export Subsidies and Countervailing Duties," Journal of International Economics 31, 1991.

Conybeare, J.A.C., Trade Wars: The Theory and Practice of International Commercial 
Rivalry, New York: Columbia University Press, 1987.

Copeland, B.R., "Tariffs and Quotas: Retaliation and Negotiation with Two Instruments of Protection," Journal of International Economics 26, 1989.

Copeland, B.R., "Strategic Interaction among Nations: Negotiable and Non-negotiable Trade Barriers," Canadian Journal of Economics 23, February 1990.

Corden,W.M., "The Normative Theory of International Trade," in R.W. Jones and P.B. Kenen (eds.) Handbook of International Economics: Volume 1, North Holland (Amsterdam), 1984.

Dam, K. W., The GATT: Law and International Economic Organization, Chicago: University of Chicago Press, 1970.

Devereux, M.B., "Growth, Specialization, and Trade Liberalization," mimeo, August 1992.

Devereux, M.B., "Sustaining Free Trade in Repeated Games without Government Commitment," mimeo, December 1993.

Dewatripont, M., and G. Roland, "Economic Reform and Dynamic Political Constraints," Review of Economic Studies, 59, 1992.

Dick, A.R., "Explaining Managed Trade: Non-cooperative Politics or Cooperative Economics?" mimeo, January 1994.

Dixit, A., "Strategic Aspects of Trade Policy," in Trewman F. Bewley, ed., Advances in Economic Theory: Fifth World Congress, New York:Cambridge University Press, 1987.

Dixit, A., "Antidumping and Countervailing Duties under Oligopoly," European Economic Review 32, 1988.

Dixit, A., "Trade and Insurance with Imperfectly Observed Outcomes," Quarterly Journal of Economics 104, 1989.

Eaton, J., and Y. Ono, "Tariff Wars, Retaliation, and Managed Trade," mimeo, January 1992.

Eaton, J. and G.M. Grossman, "Tariffs as Insurance: Optimal Commercial Policy when Domestic Markets are Incomplete," Canadian Journal of Economics 18, 1985.

Ethier, W.J., "Dumping," Journal of Political Economy 90, 1982.

Farrell, J. and E. Maskin, "Renegotiation in Repeated Games," Games and Economic Behavior 1, December 1989.

Feenstra, R.C., and T.R. Lewis, "Negotiated Trade Restrictions with Private Political Pressure," 
Quarterly Journal of Economics, November 1991.

Finger, J.M., and K.C. Fung, "Can Competition Policy Control '301'?" mimeo, August 1993.

Friedman, J., Game Theory with Applications to Economics. New York: Oxford University Press. 1986.

Fung, K.C., and R.W. Staiger, "Trade Liberalization and Trade Adjustment Assistance," in M.

Canzoneri, W. Ethier, and V. Grilli (eds.) The New Transatlantic Economy, forthcoming.

Furusawa, T., "The Negotiation of Sustainable Tariffs," in Three Essays in the New International Trade Theory, Ph.D. Dissertation, The University of Wisconsin, 1994.

Green, E.J., and R.H. Porter, "Noncooperative collusion under imperfect price information, Econometrica 52, 1984.

Grossman, G.M., and H.Horn, "Infant-Industry Protection Reconsidered: The Case of Informational Barriers to Entry," Quarterly Journal of Economics 103, (November 1988).

Grossman, G.M., and E. Helpman, "Trade Wars and Trade Talks," NBER Working Paper No. $4280,1993$.

Gruenspecht, H.K., "Dumping and Dynamic Competition," Journal of International Economics, November 1988.

Hudec, R.E., The GATT Legal System and World Trade Diplomacy, 2nd ed., Butterworth, Salem, 1975.

Hudec, R.E., "Dispute Settlement," in Jeffrey Schott (ed.) Completing the Uruguay Round. Washington, D.C.,: Institute for International Economics, 1990.

Hufbauer, G.C., and J.S. Erb, Subsidies in International Trade, MIT Press: Cambridge, 1984. Hungerford, T.L., "GATT: A Cooperative Equilibrium in a Noncooperative Trading Regime?" Journal of International Economics, November 1991.

Jackson, J., World Trade and the Law of GATT, Bobbs-Merrill Co, Inc., New York, 1969. Jackson, J., The World Trading System, MIT Press:Cambridge, MA, 1989.

Jensen, R., and M. Thursby, "Free Trade: Two Non-cooperative Equilibrium Approaches," Ohio State University Working Paper No. 58, 1984.

Johnson, H.G., "Optimum Tariffs and Retaliation," Review of Economic Studies 21, 1953-54. 
Katz, M., "Game-Playing Agents: Unobservable Contracts as Precommitments," Rand Journal of Economics, Autumn, 1991.

Kehoe, P., "Policy Cooperation Among Benevolent Governments May be Undesirable," Review of Economic Studies 56, 1989.

Kennan, J., and R. Riezman, "Do Big Countries Win Tariff Wars?" International Economic Review 29, 1988.

Kennan, J., and R.B. Wilson, "Bargaining with Private Information," Journal of Economic Literature 31, March 1993.

Kovenoch, D., and M. Thursby, "GATT, Dispute Settlement and Cooperation," Economics and Politics, July 1992.

Kowalczyk, C., and T. Sjostrom, "Bringing GATT into the Core," Economica 61, August 1994.

Kydland, F.E., and E.C. Prescott, "Rules Rather than Discretion: The Inconsistency of Optimal Plans," Journal of Political Economy 85, June 1977.

Lapan, H.E., "The Optimal Tariff, Production Lags and Time Consistency," American Economic Review 78, 1988.

Levy, P.I., "A Political-Economic Analysis of Free Trade Agreements," in Political Economy and Free Trade Agreements, Ph.D. Dissertation, Stanford University, 1994.

Ludema, R.D., "Optimal International Trade Agreements and Dispute Settlement Procedures," University of Western Ontario Working Paper, 1990.

Ludema, R.D., "International Trade Bargaining and the Most-Favored Nation Clause," Economics and Politics 3, 1991.

Ludema, R.D., "On the Value of Preferential Trade Agreements in Multilateral Negotiations," mimeo, May 1993.

Maggi, G., "The Role of Multilateral Institutions in International Trade Cooperation," in Essays on Trade Policy and International Institutions under Incomplete Information Ph.D. Dissertation, Stanford University, 1994.

Mailath, G., and A. Postlewaite, "Asymmetric Information Bargaining Problems with Many Agents," Review of Economic Studies 57, July 1990.

Maskin, E., and D. Newbery, "Disadvantageous Oil Tariffs and Dynamic Consistency," American Economic Review 80, March 1990. 
Matsuyama, K. "Perfect Equilibria in a Trade Liberalization Game," American Economic Review, June 1990.

Mayer, W., "Optimal Pursuit of Safeguard Actions over Time," in A.V.Deardorff and R.M.Stern (eds.) Analytical and Negotiating Issues in the Global Trading System. The University of Michigan Press: Ann Arbor. 1994.

McLaren, J., "Size, Sunk Costs, and Judge Bowker's Objection to Free Trade," mimeo, June 1994.

McMillan. J., "The Economics of Section 301: A Game-Theoretic Guide," Economics and Politics, March 1990.

Messerlin. P.A., "Antidumping," in J.J. Schott (ed.) Completing the Uruguay Round, Washington, D.C.: Institute for international Economics.

Mussa, M.. "The Adjustment Process and the Timing of Trade Liberalization," NBER Working Paper No. 1458, 1984.

North, D.C., "Economic Performance Through Time," American Economic Review 84, June 1994.

Ono, Y., "Orderly-Marketing Arrangements in the Context of the GATT Regime," Economics and Politics, 3, 1991.

Page, S.A.B., "The Management of International Trade," in R. Major (ed.) Britain's Trade and Exchange Rate Policy, London: Heinemann, 1979.

Pearce, D.G., "Renegotiation-Proof Equilibria: Collective Rationality and Intertemporal Cooperation," Cowles Foundation Discussion Paper No. 855.

Persson,T.. and G. Tabellini, Macroeconomic Policy, Credibility and Politics, London: Harwood, 1990.

Pinto, B., "Repeated Games and the Reciprocal Dumping Model of Trade," Journal of International Economics 20, (May 1986).

Prusa, T. J., "The Selection of Antidumping Cases for Withdrawal," in R.E. Baldwin (ed.) Empirical Studies of Commercial Policy. Chicago: The University of Chicago Press. 1991.

Prusa, T.J., "Why are so Many Antidumping Petitions Withdrawn?" Journal of International Economics, August 1992. 
Prusa, T.J., and W.L. Hansen, "The Road Most Travelled: The Rise of Title VII Protection," The World Economy, forthcoming.

Riezman, R., "Dynamic Tariffs with Asymmetric Information," Journal of International Economics 30, May 1991.

Robinson, J., "Beggar-My-Neighbor Remedies for Unemployment," Chapter 2 of Essays on the Theory of Employment, 2nd Edition: Basil Blackwell, Oxford, 1947. Reprinted as Chapter 17 of Readings in the Theory of International Trade, London: George Allen and Unwin, 1950.

Rodrik, D., "Taking Trade Policy Seriously: Export Subsidization as a Case Study in Policy Effectiveness," NBER Working Paper No. 4567, December 1993.

Rotemberg, J.J., and G. Saloner, "A Supergame-Theoretic Model of Price Wars During Booms," American Economic Review 76, (June 1986).

Rubinstein, A., "Perfect Equilibrium in a Bargaining Model," Econometrica 50, 1982.

Scitovszky, T., "A Reconsideration of the Theory of Tariffs," Review of Economic Studies 9, Summer, 1942. Reprinted as Chapter 16 of Readings in the Theory of International Trade, London: George Allen and Unwin, 1950.

Staiger, R.W., "A Theory of Gradual Trade Liberalization," in Deardorff, A., Levinsohn, J., and Stern, R. (eds.) New Directions in Trade Theory, The University of Michigan Press, forthcoming.

Staiger, R.W., and G. Tabellini, "Discretionary Trade Policy and Excessive Protection," American Economic Review, December 1987.

Staiger, R.W., and G. Tabellini, "Rules and Discretion in Trade Policy," European Economic Review, December 1989.

Staiger, R.W., and G. Tabellini, "Rules versus Discretion in Trade Policy: An Empirical Analysis," in R.E. Baldwin (ed.) Empirical Studies of Commercial Policy, The University of Chicago Press: Chicago and London. 1991.

Staiger, R.W., and G. Tabellini, "Does Commitment Matter in Trade Policy?" Economics and Politics, forthcoming.

Staiger, R.W., and F.A. Wolak, "The Effect of Domestic Antidumping Law in the Presence of Foreign Monopoly," Journal of International Economics, May 1992. 
Staiger, R.W., and F.A. Wolak, "Strategic Use of Antidumping Law to Enforce International Collusion," mimeo, March 1991.

Staiger, R.W., and F.A. Wolak, "Measuring Industry Specific Protection: Antidumping in the United States," Brookings Papers on Economic Activity: Microeconomics, 1994.

Talbot, R.B., The Chicken War: An International Trade Conflict. Ames: Iowa State University Press, 1978.

Tornell. A., "On the Ineffectiveness of Made-to-Measure Protectionist Programs," in E. Helpman and A. Razin (eds.) International Trade and Trade Policy, The MIT Press, Cambridge, MA, 1991.

Trefler. D., "Trade Liberalization and the Theory of Endogenous Protection: An Econometric Study of U.S. Import Policy," Journal of Political Economy 101, 1993.

Viner. J.. "The Most-Favored-Nation Clause in American Commercial Treaties," Journal of Political Economy, February 1924. Reprinted as Chapter 1 of International Economics, Glencoe, IL: The Free Press, 1951.

Viner. J.. "The Most-Favored-Nation Clause," Index, Sevnska Handelsbanken, Stockholm, January 1931. Reprinted as Chapter 5 of International Economics. Glencoe, IL: The Free Press, 1951.

Viner. J., "Comments on the Improvement of Commercial Relations between Nations," in The Improvement of Commercial Relations between Nations and the Problem of Monetary Stabilization, Paris: Carnegie Endowment-International Chamber of Commerce Joint Committee, 1936.

Webb. M., "A Theoretical Note on Quota-Reduction Negotiations," Oxford Economic Papers 36. June 1984.

Weinstein, D.E., "Competition and Unilateral Dumping," Journal of International Economics 32, (May 1992).

Winters. A.L., "The Road to Uruguay," in David Greenaway (ed.), "Policy Forum: Multilateralism and Bilateralism in Trade Policy: Editorial Note," Economic Journal 100, 1990.

Yarbrough, B.V., and R.M. Yarbrough, Cooperation and Governance in International Trade: The Strategic Organizational Approach. Princeton: Princeton University Press, 1992. 
Figure 1
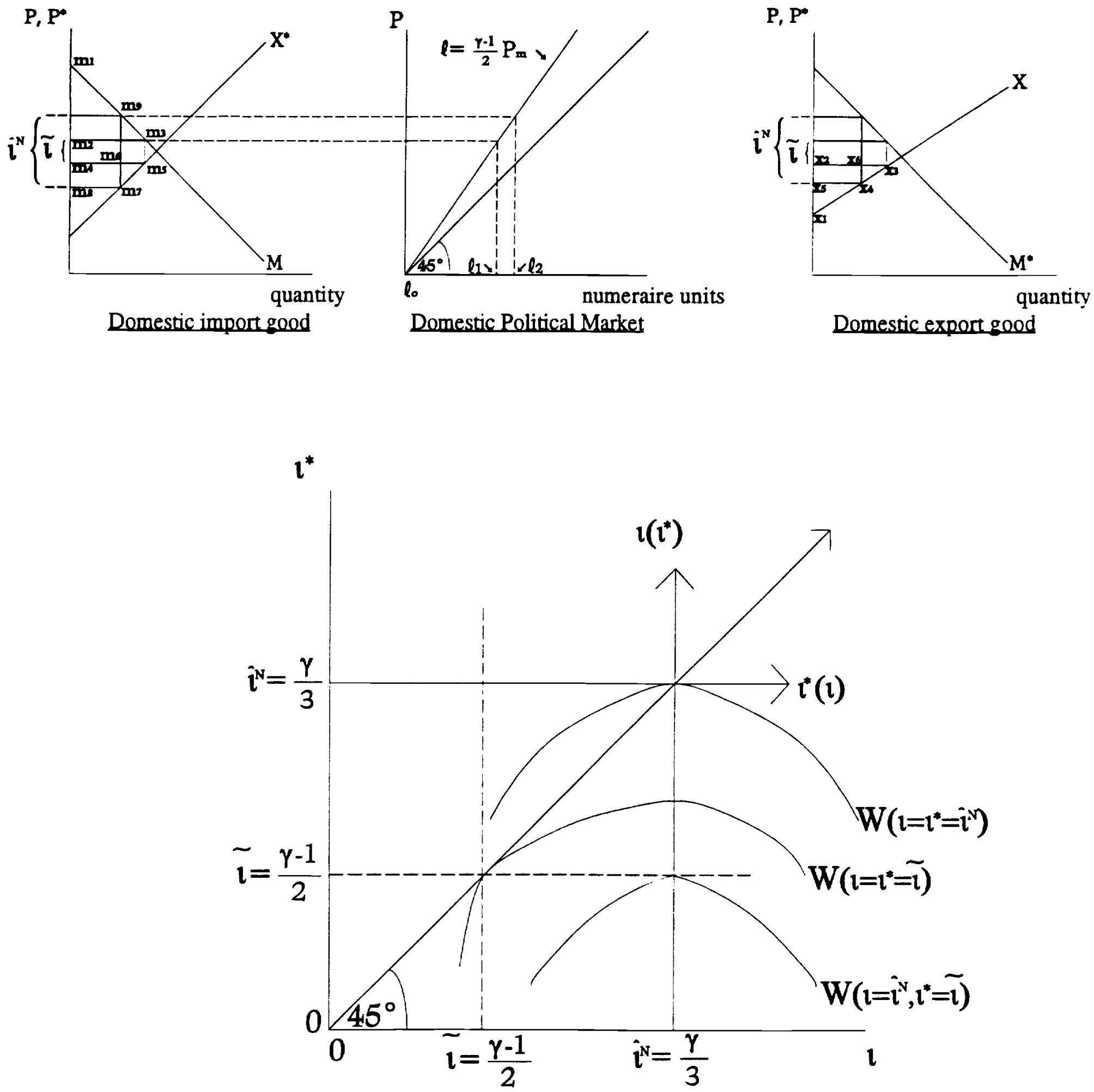


\section{EIGURE 2}

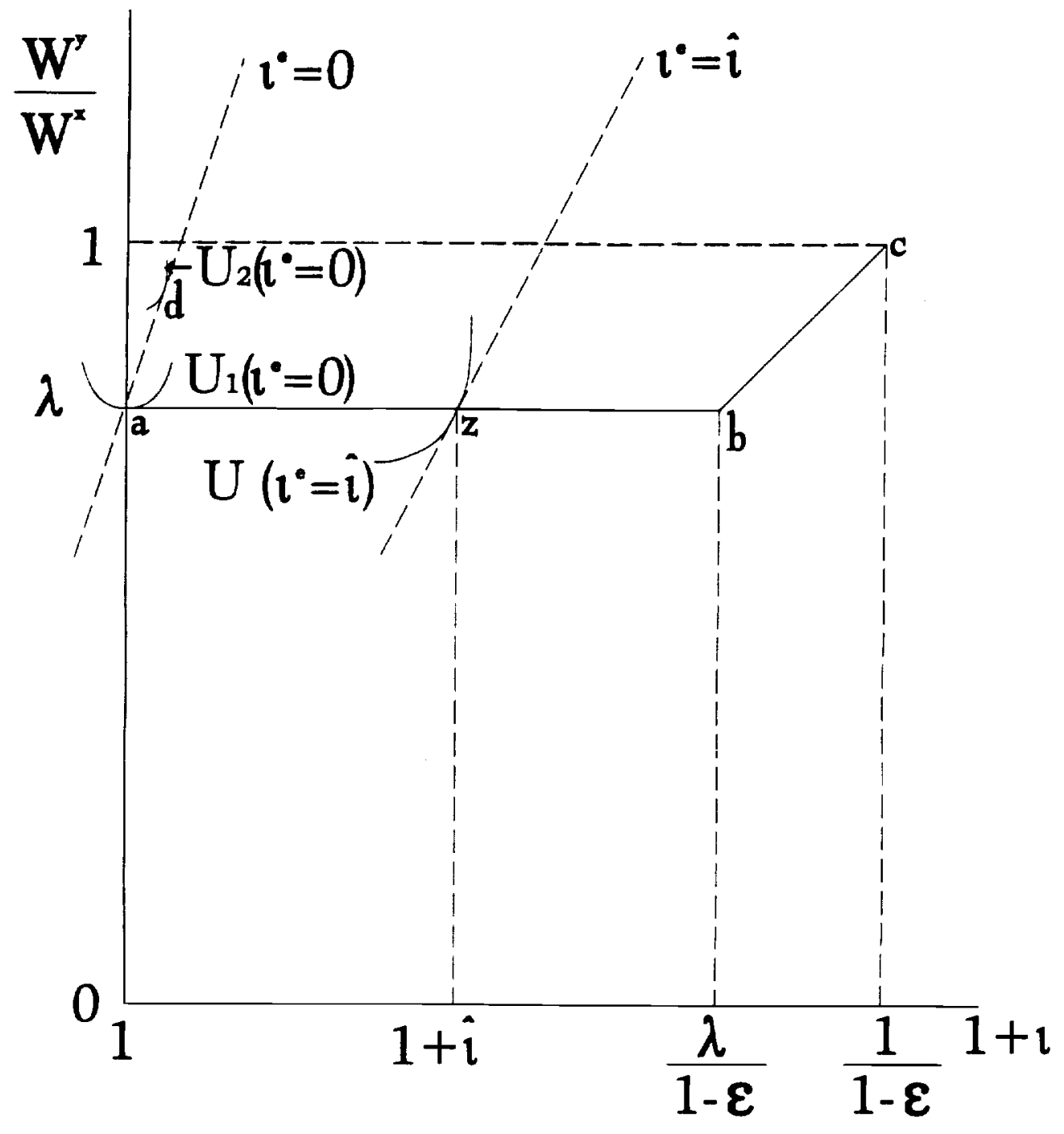




\section{FIGURE 3}

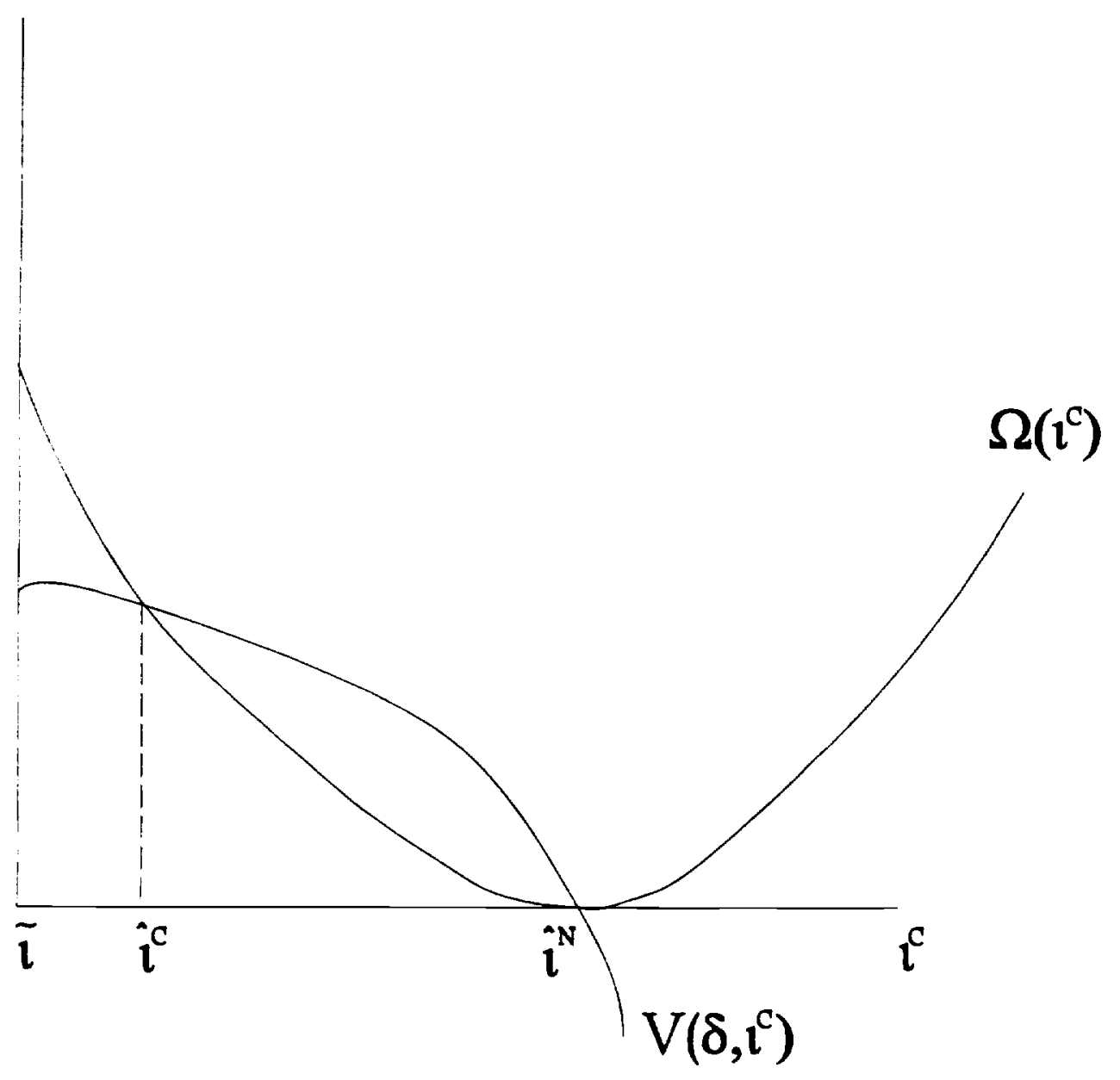

